\title{
A BACIA DE ANTEPAÍS PALEOPROTEROZÓICA SABARÁ, QUADRILÁTERO FERRIFEERO, MINAS GERAIS
}

\author{
LUCIANA ANDRADE REIS ${ }^{1}$, MARCELO A. MARTINS-NETO ${ }^{1,2}$, NEWTON SOUZA GOMES ${ }^{2}$, ISSAMU ENDO ${ }^{2}$ \\ \& HANNA JORDT-EVANGELISTA ${ }^{2}$
}

\begin{abstract}
THE PALEOPROTEROZOIC SABARÁ FORELAND BASIN, IRON QUADRANGLE, MINAS GERAIS, BRASIL The Sabará Group is a $3-3.5 \mathrm{~km}$ thick sequence composed of schists, meta-sandstones, meta-siltites, meta-conglomerates, meta-dianictites, meta-rhythmites and phyllites, whose protoliths are greywackes, sandstones, siltites, conglomerates, diamictites, rhythmites and pelites. The rocks of the Sabará Group record a significant change of depositional setting and sediment source comparing with the rest of the Minas Supergroup. The Sabará Group occurs suitable for sedimentological-stratigraphical analysis in the Dom Bosco syncline, Moeda syncline and in the Serra do Curral. The Sabará Group was divided into the following ten facies, which occur in the field arranged in coarsening-upward (CU) successions: massive conglomerate (debris flow), coarse diamictite (debris flow), fine diamictite (debris flow), mixed grey wacke (mass llow), arkosic greywacke (mass flow), tabular sandstone (turbidity currents), rhythmite (turbidity currents), siltite (low-density turbidity current), pelite (deposition of suspension) and black shale (deposition of suspension). These facies deposited in a talus fans/submarine fans/basin system tract. The Sabará Group represents foreland basin deposits related to the Transamazonian Orogeny. The clast suite of the diamictites and conglomerates points to erosion and reworking of supracrustal sequences (Minas Supergroup and Rio das Velhas Supergroup) and uplifted basement. The Sabará Group provenance plots show mixed source areas, predominating intermediate igneous and quartzose sedimentary provenance, although felsic and mafic igneous also contributed. These data indicate compartmentalized, complex source aren. The tectonic setting plots indicate a provenance from active continental margin/continental magmatic arc. The Sabará Group represents probably a Transamazonian compartmentalized foreland basin development during deformation uplift and erosion of Archean and Paleoproterozoic deposits of the Mineiro Belt. The Sabará basin, based on the location of its deposits and petrofacies, can be divided into three sub-basins: Antônio Pereira-Ouro Preto-Mariana-Rodrigo Silva, Lagoa das Codornas and Sabará-Belo Horizonte-Ibirité-Fernão Dias sub-basins.
\end{abstract}

Keywords: Basin analysis, depositional model, Sabará Group, Paleoproterozoic, Iron Quadrangle.

RESUMO Grupo Sabará é uma seqüência de $3-3,5 \mathrm{~km}$ de espessura, composta por xistos, metarenitos, metassiltitos, metaconglomerados, metadiamictitos, metarritmitos e filitos, cujos protólitos são grauvacas, arenitos, siltitos, conglomerados, diamictitos, ritmitos e pelitos. Este grupo acorre de forma susceptivel a uma análise sedimentológico-estratigráfica no Sinclinal Dom Bosco, Sinclinal Moeda e na Serra do Curral. O Grupo Sabará foi dividido, neste traballho, nas seguintes fácies, que ocorrem organizadas em sucessões em granocrescência ascendente (CU): conglomerado maciço (fluxo de detritos), diamictito grosso (fluxo de detritos), diamictito fino (fluxo de detritos), grauvaca mista (fluxo de massa), grauvaca arcosiana (fluxo de massa), arenito tabular (conrentes de turbidez), ritmito (correntes de turbidez), siltito (estágios finais de conrentes de turbidez), pelito (deposicão da suspensão) e folhello negro (deposição da suspensão), depositados em umn sistema de leques proximais/leques submarinos/bacia. $O$ Grupo Sabará representa os depósitos de uma bacia do tipo antepaís relacionada com a Evento Transamazônico. Os clastos presentes nos diamictitos e conglomerados indicam retrabalhamento de sequiências supracrustais e do embasamento (Supergrupo Minas, Supergrupo Rio das Velhas e o embasamento soerguido). Os diagramas de proveniência plotados para o Grupo Sabará apontarn para uma mistura de áreas fontes, predominando a proveniência ígnea intermediária e sedimentar quartzosa, embora proveniências ígnea félsica e ígnea máfica também ocorram, indicando compartimentação da área fonte. Os diagramas de proveniência por ambiente tectônico indicam uma proveniência de margem continental ativa/arco magmático continental. O Grupo Sabará representa provavelmente uma bacia de antepaís compartimentada, formada durante a deformação soerguimento e erosão dos depósitos arqueanos e paleoproterozóicos do Cinturão Mineiro, de idade transamazônica. Esta bacia foi dividida em três sub-bacias: Sub-bacia Antônio Pereira-Ouro Preto-Mariana-Rodrigo Silva, Sub-bacia Lagoa das Codornas e Sub-bacia Sabará-Belo Horizonte-lbiritéFernão Dias com base na localização geográfica dos depósitos do Grupo Sabará em relação ao embasamento e supracrustais do Quadrilátero Ferrífero e nas suas petrofácies.

Palawras-chave: Análise de bacias, modelo deposicional, Grupo Sabará, Paleoproterozóico, Quadrilátero Ferrífero

INTRODUÇÃO O Grupo Sabará (Renger et al. 1994, ou Formação Sabará de Gair 1958, Dorr II 1969) é uma seqüência e de $3-35 \mathrm{~km}$ de espessura composta por xistos, filitos, metarenitos, metavulcanoclásticas, metaconglomerados e metadiamictitos (Dorr II 1969, Barbosa 1979, Renger et al. 1994, Alkmim \& Marshak 1998). Não existem na literatura modelos deposicionais sistematicamente construídos para esta unidade, apenas hipóteses de trabalho, erigidas na sua maioria através de mapeamentos geológicos (Dorr II 1969 - "eugeossinclinal do Geossinclinal Minas"), estudos de integração de dados tectônicos (Alkmim \& Marshak 1998 - "bacia de antepaís da Orogênese Transamazônica") e/ou geocronológicos
(Renger et al. 1994 - "fácies sin-orogênica do Evento Transamazônico").

As hipóteses mais recentes indicam para o Grupo Sabará uma deposição em uma bacia do tipo de antepaís relacionada ao Evento Transamazônico, cuja sucessão seria do tipo flysch (Barbosa 1968, Dorr II 1969, Renger et al. 1994, Noce 1995, Alkmim \& Marshak 1998).

O presente trabalho, em caráter inédito, tem como objetivo a caracterização da evolução sedimentar do Grupo Sabará, visando a apresentação de um modelo deposicional para este grupo, bem como checar a hipótese de deposição em bacia de antepaís. O estudo teve um caráter multidisciplinar, integrando

1 NUPETRO - Núcleo de Geologia do Petróleo - Fundação Gorceix, Ouro Preto/MG

2 Departamento de Geologia Escola de Minas Universidade Federal de Ouro Preto - Caixa Postal 173 - 35400-000 - Ouro Preto/MG, lucianaandradereis@hotmail.com - neto@degeo.ufop.br 
dados petrográficos/petrológicos, litoquímicos, de fácies sedimentares, estratigráfïcos e tectônicos.

A área estudada encontra-se dividida em três setores: Setor I (Antônio Pereira, Mariana, Ouro Preto e Rodrigo Silva), Setor II (Lagoa das Codornas) e Setor III (Sabará, Belo Horizonte, Ibirité e Rodovia Fernão Dias), definidas de acordo com a distribuição dos afloramentos do Grupo Sabará (Fig. 1). O alto grau de alteração das rochas e a escassez de afloramentos limitaram a área de estudo.

Contexto Regional O Quadrilátero Ferrífero ocupa uma área de aproximadamente $7.190 \mathrm{~km}^{2}$ na porção central do Estado de Minas Gerais, encontrando-se parcialmente inserido no extremo sudeste do cráton do São Francisco e parcialmente na
Faixa Araçuaí, de idade brasiliana. São reconhecidas na região, além de complexos granítico-gnáissicos (Noce 1995), uma sucessão tipo greenstone belt de idade arqueana (Supergrupo Rio das Velhas) (Carneiro et al. 1998), além de supracrustais do Paleoproterozóico (Supergrupo Minas e Grupo Itacolomi) (Dorr II 1969, Machado et al. 1996, Alkmim \& Marshak 1998) (Fig. 2).

O Supergrupo Minas é uma sequência metassedimentar de idade paleoproterozóica (Babinski et al. 1991), interpretado como uma bacia intracratônica (Chemale et al. 1994) ou como uma sequência supracrustal de plataforma com substrato siálico (Marshak \& Alkmim 1989). As rochas do Supergrupo Minas foram sujeitas ao metamorfismo da fácies xisto verde atingindo a fácies anfibolito nas porções leste, sudeste e nor-

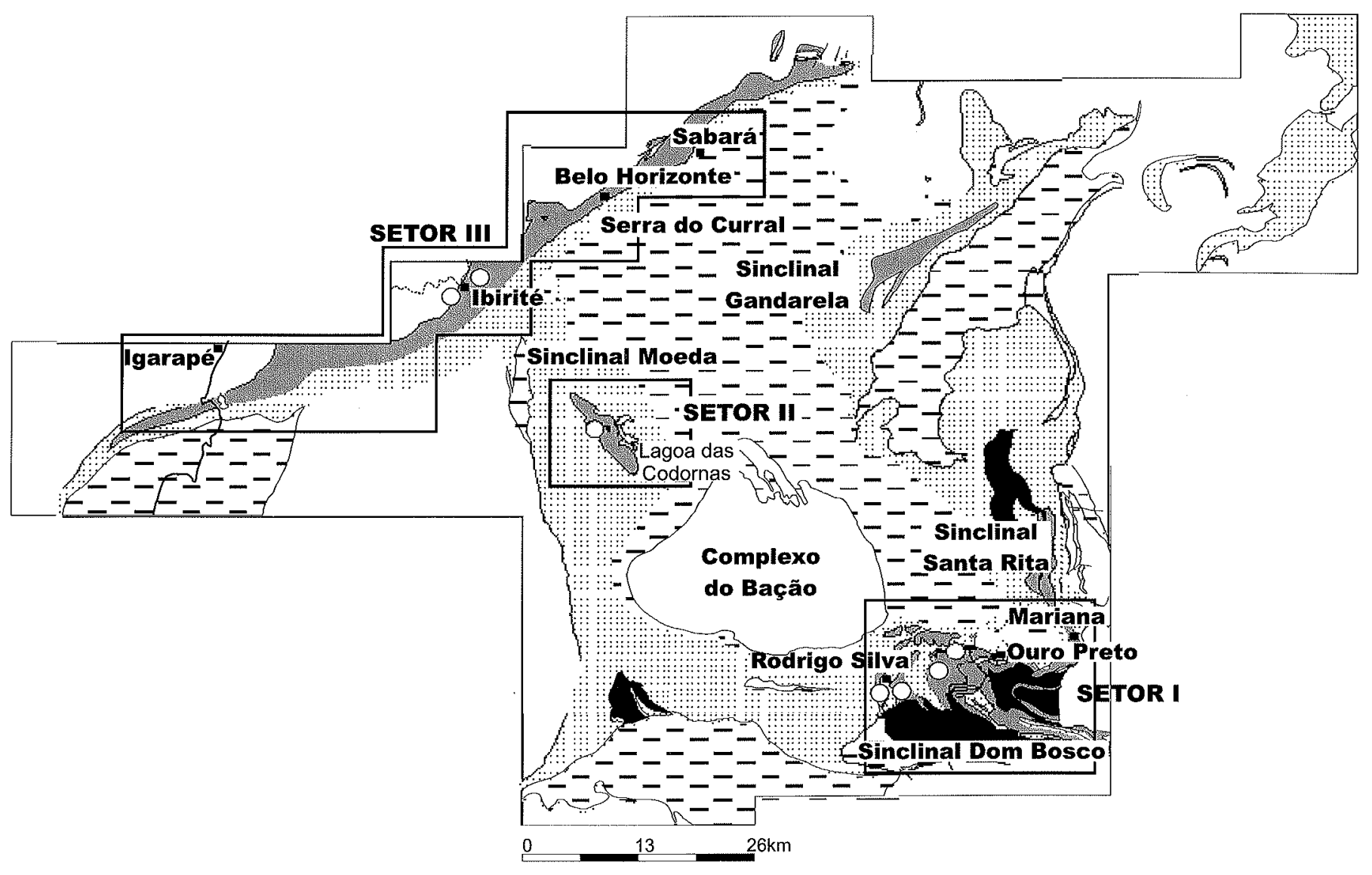

\section{LEGENDA}

Grupo Itacolomi

Grupo Sabará

::: Supergrupo Minas

[-] Supergrupo Rio das Velhas

$\square$ Embasamento

Setores Estudados
- Cidades

Estrada São Paulo -

Belo Horizonte

Estrada de Ferro Central do Brasil

- Localização aproximada das colunas estratigráfica/ sedimentológicas levantadas

Figura I - Mapa de localização das áreas estudadas (setores) dentro do Quadrilátero Ferrífero, indicando localidades citadas no texto. 


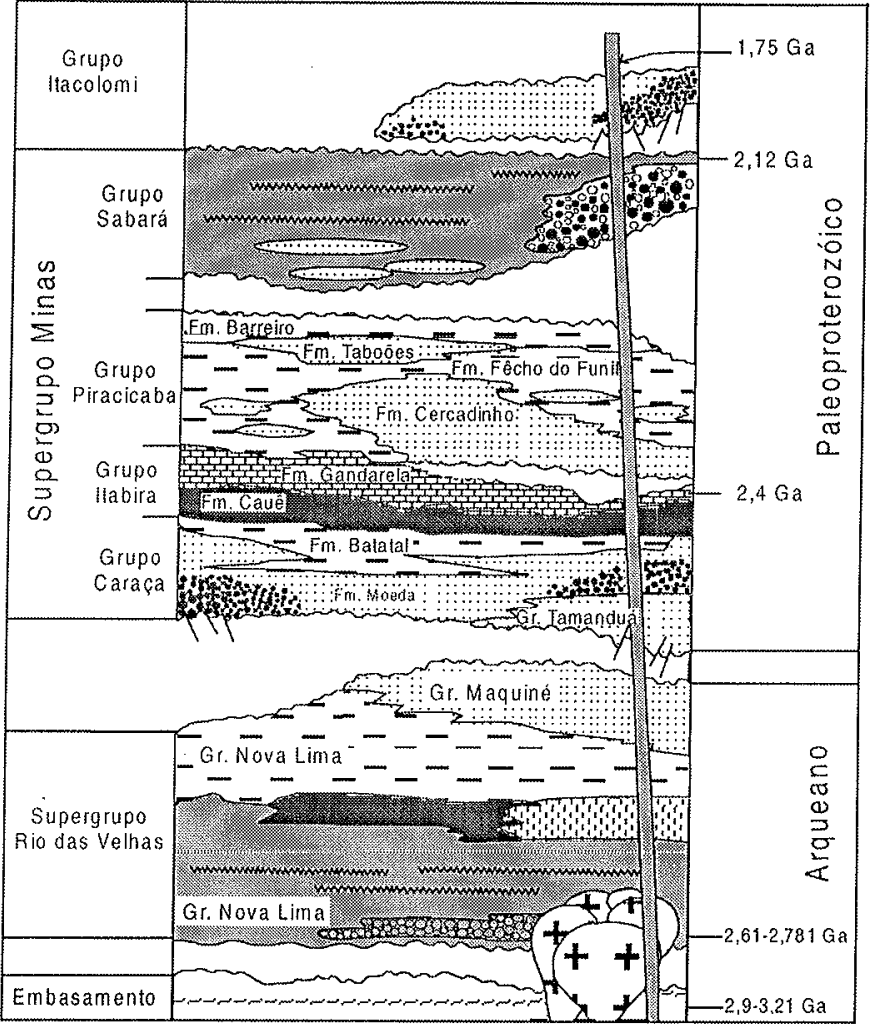

\begin{tabular}{|c|c|}
\hline Metaconglomerados & Formações Ferríteras \\
\hline Sato Metadiamictitos & Metarenitos \\
\hline 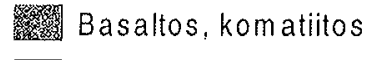 & Metapelitos \\
\hline Metavulcânicas & Granitóides \\
\hline $\begin{array}{l}7 \text { Gnaisses, migmatitos } \\
\text { Carbonatos }\end{array}$ & \Diques máficos \\
\hline
\end{tabular}

Figura 2 - Coluna estratigráfica do Quadrilátero Ferrífero conforme Alkmim \& Marshak (1998).

deste do Quadrilátero Ferrífero (Herz 1970). Esta unidade está em contato tectônico com o Supergrupo Rio das Velhas e os complexos granito-gnáissicos (Machado et al. 1996). Estratigraficamente, o Supergrupo Minas é composto pelos grupos Tamanduá, Caraça, Itabira, Piracicaba e Sabará (Dorr II 1969, Alkmim 1987, Rodrigues et al. 1993). O Grupo Sabará (Barbosa 1968, Renger et al. 1994), antiga Formação Sabará de Gair (1958), é a unidade superior do Supergrupo Minas, consistindo de um espesso pacote de $3-3,5 \mathrm{~km}$ de espessura composto por rochas clásticas localmente intercaladas com sedimentos químicos e rochas vulcânicas.

Segundo Machado \& Noce (1993), a idade da deposição do Grupo Sabará pode ser balizada pelo Evento Transamazônico, no intervalo de 2125 e $2045 \mathrm{Ma}$, com duração de cerca de 80 m.a.. A idade máxima para a deposição do Grupo Sabará é balizada pela datação U-Pb de um zircão detrítico idiomórfico com $2125 \pm 4 \mathrm{Ma}$ (Machado et al. 1989,1992) ou $2131 \pm 5 \mathrm{Ma}$ (Machado et al. 1996), idades coincidentes com o início do Evento Transamazônico. A idade mínima para o Grupo Sabará não foi ainda bem determinada. Datações $U / P b$ em zircões detríticos do sobreposto Grupo Itacolomi dão uma idade de 2059 $\pm 58 \mathrm{Ma}$ (Machado et al. 1996).

PETrografia E PETrologia O Grupo Sabará é constituído pelos seguintes litotipos: metaconglomerados, metadiamictitos, metarenitos, xistos, metaritmitos e filitos. A Tabela I mostra uma síntese relacionando litotipo metamórfico e protólito sedimentar:

FÁCIES SEDIMENTARES O Grupo Sabará é constituído pelas seguintes fácies sedimentares (Tabela 2), definidas através de um levantamento sedimentológico sistemático: conglomerado maciço $(\mathrm{Gm})$, diamictito grosso (Dg), diamictito fino (Df), grauvaca mista $(\mathrm{Wm})$, grauvaca arcosiana $(\mathrm{Wa})$, arenito tabular (A), ritmito $(\mathrm{R})$, siltito $(\mathrm{S})$, pelito $(\mathrm{P})$ e folhelho negro $(\mathrm{Fn})$ (Figs. 3, 4, 5).

RELAÇÃO VERTICAL DAS FÁCIES As fácies do Grupo Sabará estão arranjadas em sucessões de aproximadamente $760 \mathrm{~m}$ de espessura em granocrescência ascendente (CU coarsenig-ıpward). Várias sucessões em CU de aproximadamente 8 a $280 \mathrm{~m}$, hierarquicamente inferiores, ocorrem dentro das sucessões maiores (Figs. 6, 7, 8, 9, 10, 11). Estes intervalos correspondem a intervalos tectono-deposicionais, que são definidos como intervalos estratigráficos com fácies geneticamente relacionadas, depositadas durante um período tectônico distinto dentro de uma fase tectônica da bacia (Da Silva 1993). Cada intervalo tectono-deposicional representa um evento progradacional com sequiências em CU. As porções finas basais representam taxas de geração de espaço de acomodação maiores que de suprimento sedimentar, enquanto os topos mais grossos indicam que o suprimento sedimentar suplantou a geração de espaço com o tempo.

Os intervalos tectono-deposicionais, presentes na região de Ouro Preto (Setor I, Figs. 6, 7), iniciam-se normalmente com grauvacas mistas e, localmente, com grauvacas arcoseanas, embora alguns intervalos tectono-deposicionais comecem com ritmitos, pelitos ou folhelho negro (Fig. 6). À medida que as condições proximais avançavam, estas fácies gradaram para fácies mais grossas, tais como diamictitos finos e grossos. Os intervalos tectono-deposicionais que iniciam com ritmitos, pelitos ou folhelho negro gradam para grauvacas e/ou arenitos antes de atingir as fácies mais grossas (Fig. 6). Localmente, tem-se a passagem de pelitos para diamictitos finos, sem a deposição das fácies intermediárias (grauvacas ou arenitos). Alguns intervalos tectono-deposicionais evoluem de forma diferente, ou seja, iniciam com grauvacas, gradam para pelitos, novamente gradam para grauvacas e, posteriormente, para diamictitos.

Na Lagoa das Codornas (Setor II, Fig. 8), o intervalo tectono-deposicional inicia-se com grauvacas que gradam para siltitos, pelitos, novamente siltitos, e posteriormente gradam para diamictitos grossos. Neste intervalo, observa-se a deposição de um pacote pelítico entre os pacotes de diamictitos, representando provavelmente uma queda no suprimento sedimentar para a bacia ou um pequeno pulso de subsidência. O suprimento de sedimentos é novamente retomado e depositam-se então as fácies proximais como diamictitos grossos e conglomerado, mostrando a progradação do lobo deposicional.

Na região de Ibirité (Setor III, Figs .9, 10), os intervalos tectono-deposicionais são formados por fácies mais distais, ou seja, por grauvacas, arenitos, siltitos e pelitos. As fácies mais 
Tabela I - Síntese relacionando litotipo metamórfico e protólito sedimentar do Grupo Sabará.

\begin{tabular}{|c|c|c|}
\hline $\begin{array}{c}\text { ROCHA } \\
\text { METAMÓRFICA }\end{array}$ & $\begin{array}{l}\text { PROTÓLITO } \\
\text { SEDIMENTAR }\end{array}$ & DESCRIÇÃO \\
\hline Metaconglomerado & Conglomerado & $\begin{array}{l}\text { Clasto-suportados, polimíticos, mal selecionados, com seixo a matacão de metarenito } \\
\text { branco, cinza e rosa e, subordinadamente, granitóide, quartzo, xisto carbonoso e } \\
\text { formação ferrífera, com grau de arredondamento variando de subarredondado a } \\
\text { subanguloso. A matriz é pelítica, podendo ocorrer matriz grauvaqueana }\end{array}$ \\
\hline Metadiam ictito grosso & Diamictito grosso & $\begin{array}{l}\text { Grânulos a blocos angulosos a subarredondados de metarenitos, formação ferrífera, } \\
\text { dolonito, filitos, granitóides e quartzo. Matriz composta por sericita e clorita, mais } \\
\text { Iração areia (fina a grossa, mal selecionada) composta por fragmentos de quartzo } \\
\text { mono e policristalino, metachert e opacos. A matriz verdadeira (15\%) confunde-se } \\
\text { compseudo-matriz }\end{array}$ \\
\hline Metadiamictito fino & Diamictito fino & $\begin{array}{l}\text { Grânulos (raros seixos e callaus) sub-angulosos a sub-arredondados de granitóides, me- } \\
\text { larenitos, de ferrífera lormação ferrifera, dolom ito, filitos e quartzo. A fração areia da } \\
\text { matriz (lina a grossa, mal selecionada) é composta por fragmentos de plagioclásio, mi- } \\
\text { croclina, quartzo e opacos, inclusos numa fração pelítica constituída por clorita e sericita }\end{array}$ \\
\hline Xisto misto & Grauvaca mista & $\begin{array}{l}\text { Fraçio areia com posta por quartzo mono e policristalino e fragmentos líticos } \\
\text { predominantemente de filitos. Localmente fragmentos de feldspatos. A matriz é } \\
\text { consituída por mica branca, sericita, biotita em algumas amostras, leucoxênio, limonita } \\
\text { (secundária), copacos }\end{array}$ \\
\hline $\begin{array}{l}\text { Sericita-quartzo- } \\
\text { feldspato xisto }\end{array}$ & $\begin{array}{l}\text { Grauvaca } \\
\text { arcoseana }\end{array}$ & $\begin{array}{l}\text { Rica em componentes feldspáticos e, subordinadamente, componentes quartzosos e } \\
\text { líticos (granitóides) }\end{array}$ \\
\hline Metarenito & $\begin{array}{c}\text { Arenito } \\
\text { quartzoso }\end{array}$ & $\begin{array}{l}\text { Mal selecionados, finos a médios, compostos, na região de Ibirité, por quartzo mono e } \\
\text { policristalino, feldspatos (plagioclásio e microclina) e metachert. A matriz. localmente } \\
\text { presente, ćcomposta por quartzo, albita, epidoto, opacos, sericita e clorita. Arenitos da } \\
\text { região de Ouro Prelo são compostos predominantemente por quartzo mono ou } \\
\text { policristalino (70 a } 90 \% \text { ), mica branca, clorita, antigorita e cloritóide em algumas } \\
\text { Amostras, limonita e opacos }\end{array}$ \\
\hline Metarritmito & Ritmito & $\begin{array}{l}\text { Compostos por lâm inas milimétricas predominantemente de quartzo e lâminas ricas em } \\
\text { sericita e clorita. Algumas lâm inas são constituídas por quartzo, sericita c clorita em } \\
\text { proporçós aproximadamente iguais. Níveis filíticos ricos em sericita, clorita, minerais } \\
\text { opacos prismáticos e quartzo granular e alongado. }\end{array}$ \\
\hline Melassiltito & Sillito & Finamente laminados, compostos por quartzo e sericita \\
\hline Filito & Polito & $\begin{array}{l}\text { Compostos por scricita e em pequena porcentagem, quartzo, opacos e zireão, apatita, } \\
\text { epidoto e turmalina como acessórios. Em algumas amostras ocorre zeólita }\end{array}$ \\
\hline Filito Negro & Folhelho Negro & Graficosos (carbonosos) \\
\hline
\end{tabular}

grossas, como diamictitos e conglomerados ocorrem localmente em afloramentos esparsos, intercalados com diamictitos grossos. A Fig. 9 mostra um intervalo tectono-deposicional iniciando com grauvaca com finas intercalações de arenitos, que gradam para arenitos finos e médios. A maioria das camadas de arenitos ocorre amalgamada, representando provavelmente a erosão ou não deposição dos pelitos. Na seção levantada a leste de Ibirité (Fig. 10), as fácies também são distais, na sua maioria amalgamadas e arranjadas localmente em sucessões em CU. Os intervalos tectono-deposicionais iniciam com pelitos ou siltitos e gradam para arenitos finos ou médios. Nesta mesma seção, aproximadamente em 154 a $166 \mathrm{~m}$, observa-se um espessamento ascendente das camadas (thickening-upward), indicando provavelmente uma progradação do lobo deposicional (Walker 1984, 1992).

MODELO DEPOSICIONAL O modelo deposicional proposto para o Grupo Sabará corresponde a uma adaptação ao modelo leque submarino de Walker (1978). As fácies do Grupo Sabará correspondem a depósitos de fluxo de detritos, fluxo de massa e turbiditos proximais, intermediários e distais em ambiente aquoso (Fig. 12). Portanto, o modelo proposto para este grupo é de leque submarino com planície de bacia. Adicionalmente, conglomerados e diamictitos representariam leques de encosta proximais (Fig. 12).

O modelo de leques submarinos proposto para o Grupo Sabará é constituído por canal(is) de alimentação, declive da bacia, leque superior, leque médio, leque inferior e planície de bacia. O leque superior normalmente é constituído por facies de canal, intercaladas com leques de encosta proximais. O leque médio é formado por vários lobos canalizados ou não, enquanto o leque inferior é constituído por leques distais nãocanalizados. Os leques canalizados alimentam os lobos deposicionais, sendo denominados de supraleques (Normark 1978). As fácies do Grupo Sabará podem ser associadas ao declive, ao leque e à planície bacinal (Mutti e Ricci Lucchi 1972), como mostra a Fig. 12. A alimentação do leque submarino foi feita, provavelmente, através de vários canais de alimentação que se dispersaram dentro da bacia.

Outro modo de alimentação foi proporcionado pelos leques de encosta proximais, através de fluxos de massa oriundos de uma fonte relativamente próxima (Fig. 12). Desta forma, as 
Tabela 2 - Fácies sedimentares do Grupo Sabará.

\begin{tabular}{|c|c|c|c|}
\hline Fácies & Características Litológicas & $\begin{array}{c}\text { Feições } \\
\text { Sedimentares }\end{array}$ & $\begin{array}{c}\text { Processos } \\
\text { Deposicionais }\end{array}$ \\
\hline $\begin{array}{l}\text { Gm - } \\
\text { Conglomerado } \\
\text { maciço }\end{array}$ & $\begin{array}{l}\text { Conglom erado clasto suportado com clastos (seixos a } \\
\text { matacóes) predominantemente de arenito branco, cinza } \\
\text { E rosa, localmente predominando embasamento ou } \\
\text { dolomito. Matriz siltergilosa, localmente arenosa }\end{array}$ & $\begin{array}{c}\text { maciço, năo gradado; } \\
10.20 \% \text { de matriz }\end{array}$ & Fluxo de detritos \\
\hline $\begin{array}{c}\text { Dg - Diamictito } \\
\text { grosso }\end{array}$ & $\begin{array}{l}\text { Diamictito com clastos (seixos a matacóes) } \\
\text { subarredondados a subangulosos predominantem ente } \\
\text { de arenito branco, cinza e rosa, localmente } \\
\text { predominando embasamento ou dolomito, } \\
\text { subordinadamente quartzo, pelitos e formaçoes } \\
\text { ferriferas. Matriz grauvaquiana, localmente grafitosal ou } \\
\text { arenosa }\end{array}$ & Proporçóes variadas clastos/matriz & Fluxo de detritos \\
\hline $\begin{array}{l}\text { Df - Dian ictito } \\
\text { fino }\end{array}$ & $\begin{array}{l}\text { Diamictito con grânulos (localmente scixos ou } \\
\text { callaus csparsos) subarredondados a subangulosos } \\
\text { predominantemente de embasamento e arenitos, e } \\
\text { subordinadamente de quartzo, pelitos, pelitos } \\
\text { dolomiticos, chert, e formação ferrifera. Matriz } \\
\text { grauvaquiana, localmente grafitosa ou arenosa }\end{array}$ & Proporçōes variadas clastos/matriz & Fluxo de detritos \\
\hline $\begin{array}{c}\text { Wm - Grauvaca } \\
\text { mista }\end{array}$ & $\begin{array}{l}\text { Grauvaca com matriz ora sillosa, ora argilosa } \\
\text { (localmente grafitosa) e variadas proporções de } \\
\text { componentes quartzosos e líticos e, subordinadamente, } \\
\text { feldspáticos. Localmente clastos (grânulos a calhaus) } \\
\text { esparsos de arenito branco ou cinza, e, } \\
\text { subordinadamente, de cherle lormação lerrífera } \\
\end{array}$ & Localmente bandada & Fluxo de massa \\
\hline $\begin{array}{l}\text { Wa - Grauraca } \\
\text { arcoseana }\end{array}$ & $\begin{array}{l}\text { Grauvaca com alta proporção de componentes } \\
\text { feldspáticos e subordinadamente quartzosos e líticos, } \\
\text { rosa e com muto caulim na matriz quando alterada. } \\
\text { Localmente com grânulos esparsos de embasamento e } \\
\text { arenitos ou somente de embasamento }\end{array}$ & 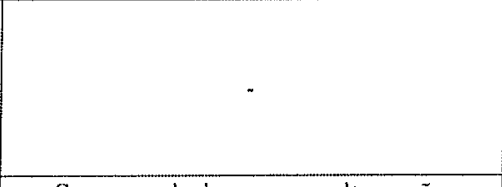 & Fluxo de massa \\
\hline $\begin{array}{l}\text { A - Arenilo } \\
\text { Tabular. }\end{array}$ & $\begin{array}{l}\text { Arenitos médios a muito finos, em camadas } \\
\text { centimétricas a métricas. amalgamadas ou separadas } \\
\text { por camadas milimétricas a métricas de pelito cinza e } \\
\text { gravaca. }\end{array}$ & $\begin{array}{c}\text { Corpos tabulares com alta razão } \\
\text { continuidade lateral } x \text { cspessura; } \\
\text { maciços ou, localmente, com gradação } \\
\text { normal, lam inaça plano-paralela e/ou } \\
\text { bandamento granulométrico e } \\
\text { composicional e climbing ripples no } \\
\text { topo da camada elou marcas de sola na } \\
\text { base }\end{array}$ & $\begin{array}{l}\text { Correntes de } \\
\text { turbidez }\end{array}$ \\
\hline R - ritmito & $\begin{array}{l}\text { Ritmito consistindo de intercalaçōes de lâminas de } \\
\text { pelito, siltito e areia fina. A presentam teor de grafite } \\
\text { variável. Localmente com grânulos a blocos } \\
\text { subarredondados a subangulosos esparsos de arenito } \\
\text { branco, amarelo e cinza. Localmente, lâminas de } \\
\text { arenito }\end{array}$ & $\begin{array}{l}\text { Lam inação plano-paralela, } \\
\text { bandamento granulométrico e } \\
\text { composicional }\end{array}$ & $\begin{array}{l}\text { Correntes de } \\
\text { turbidez de baixa } \\
\text { densidade }\end{array}$ \\
\hline S - Sillitos & Sillitos cinza, intercalados ou nấ com arenito tabular & $\begin{array}{l}\text { Lam inação plano-paralcla, } \\
\text { ligeiram ente bandada }\end{array}$ & $\begin{array}{l}\text { Deposiçăo de } \\
\text { suspensăo }\end{array}$ \\
\hline P. Pelitos & $\begin{array}{l}\text { Pelitos silto -argilosos cinza. Localmente apresentam } \\
\text { niveis arenosos }\end{array}$ & Laminação plano-paralela & $\begin{array}{c}\text { Deposição de } \\
\text { suspensão }\end{array}$ \\
\hline $\begin{array}{l}\text { Fin- Folhelho } \\
\text { negro }\end{array}$ & Folhelhos carbonosos escuros & Laminação plano-paralela & $\begin{array}{l}\text { Deposição de } \\
\text { suspensão; } \\
\text { condições } \\
\text { anóxicas }\end{array}$ \\
\hline
\end{tabular}

fácies mais grossas do Grupo Sabará, tais como as fácies Conglomerado Maciço, Diamictito Grosso e Diamictito Fino teriam se depositado em leques de encosta proximais ou na parte interna dos canais de alimentação. Estas fácies correspondem a fases de grande aporte sedimentar para bacia, provavelmente em fases entre pulsos tectônicos, onde as taxas de suprimento sedimentar eram maiores que as taxas de geração de espaço de acomodação.
A fácies Grauvaca Arcoseana e, principalmente, a Fácies Grauvaca Mista estão presentes nos lobos e nos interlobos, ocorrendo em todas as partes do leque submarino e na planície de bacia (Fig. 12).

Os turbiditos da Fácies Arenito Tabular ocorrem nas porções mais distais dos lobos de supraleque, bem como nos leques inferiores, mostrando trends de proximalidade-distalidade (Fig. 12). 

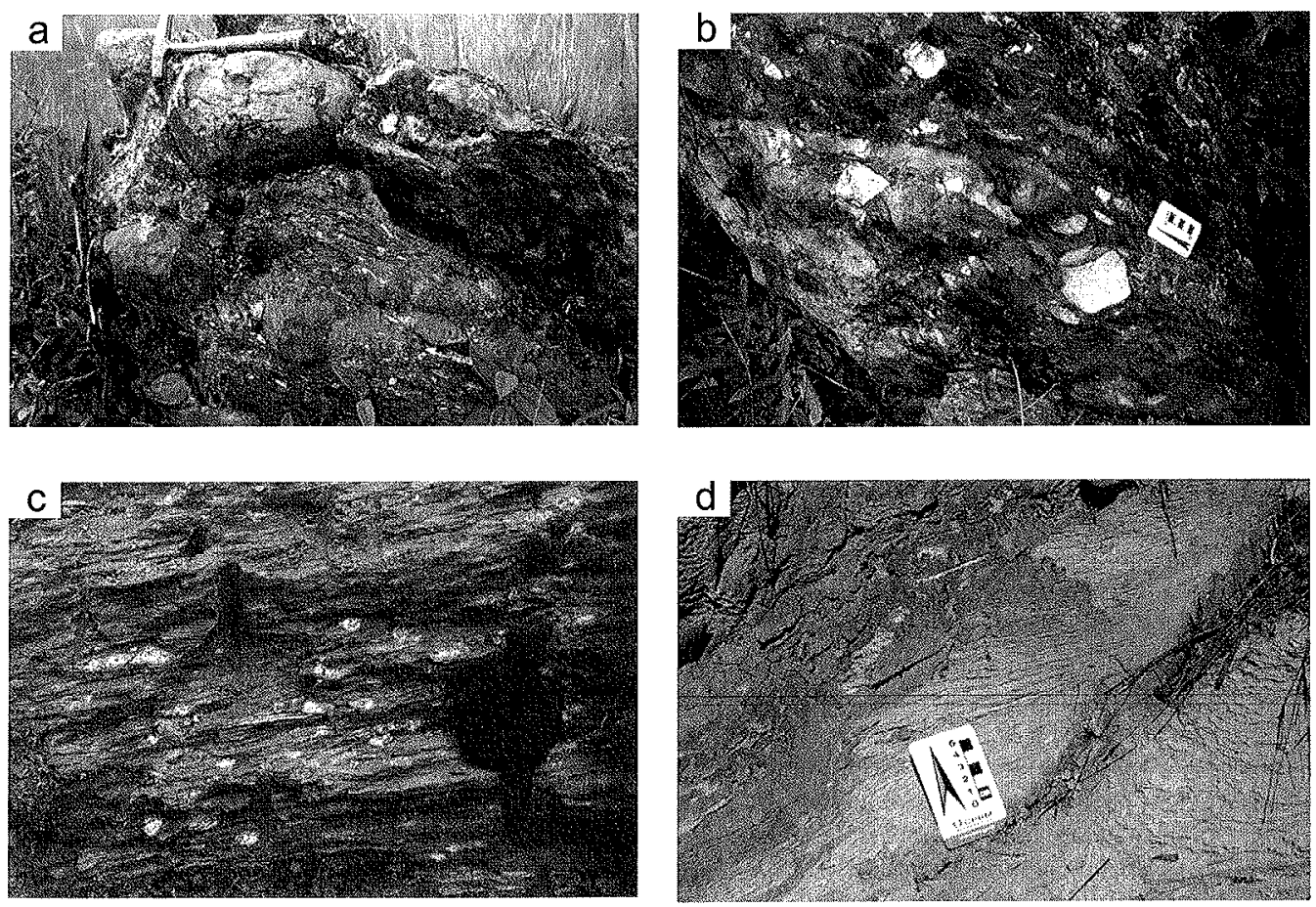

Figura 3 - Facies (a) conglomerado maciço (Lagoa das Codornas), (b) dianictito grosso (Lagoa das Codornas), (c) diamictito fino (Rodovia do Contorno de Ouro Preto), (d) Pelito (Rodovia do Contorno de Ouro Preto).
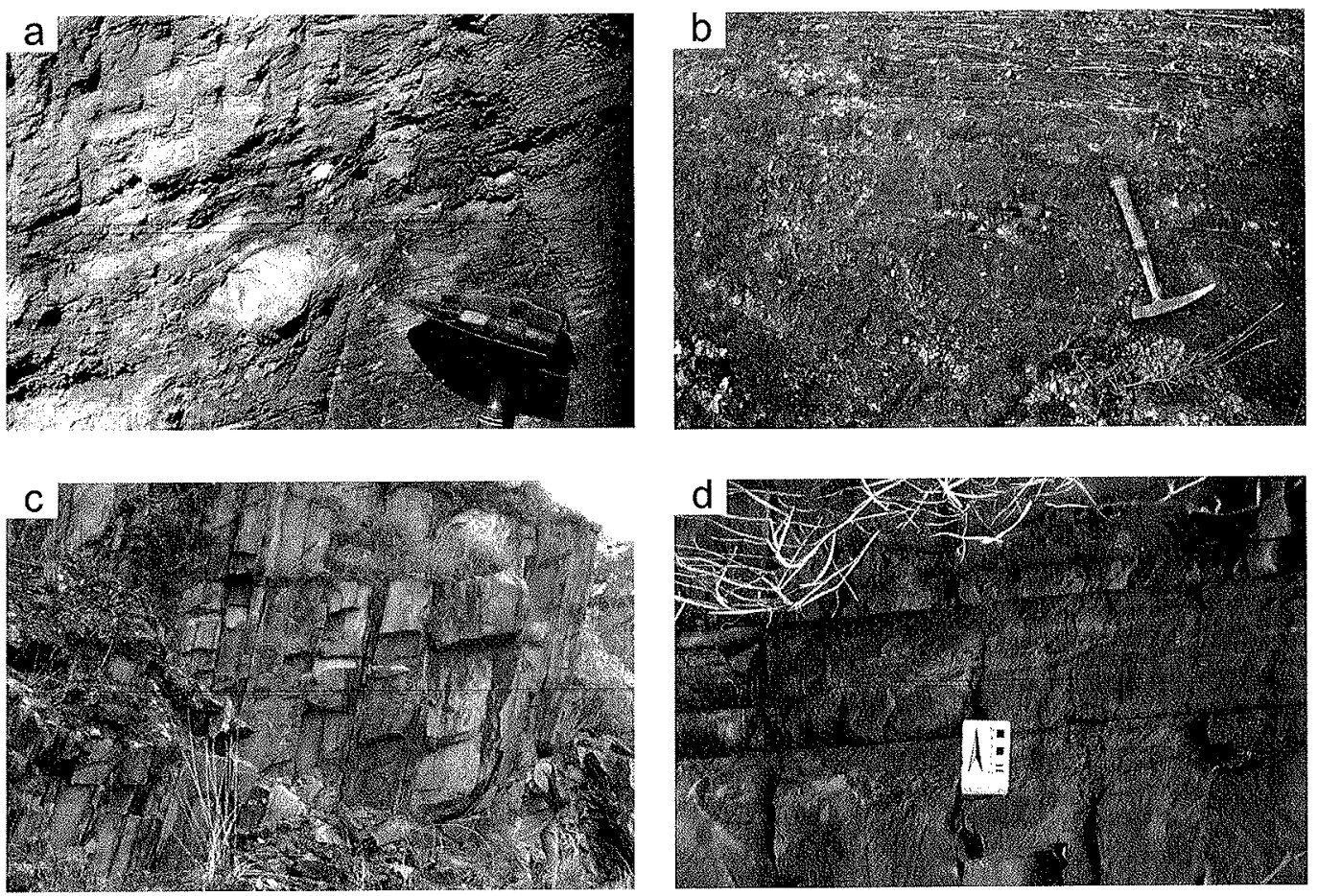

Figura 4 - Facies (a) grauvaca mista (Estrada Real), (b) grauvaca arcoseana (Rodovia do Contorno de Ouro Preto), (c) arenito tabular (Ibirité). Notar espessamento ascendente das camadas ("thickening upward") da esquerda para a direita, (d) detalhe de arenito turbidítico de Ibirité exibindo elementos ala Sequîencia de Bouma. 

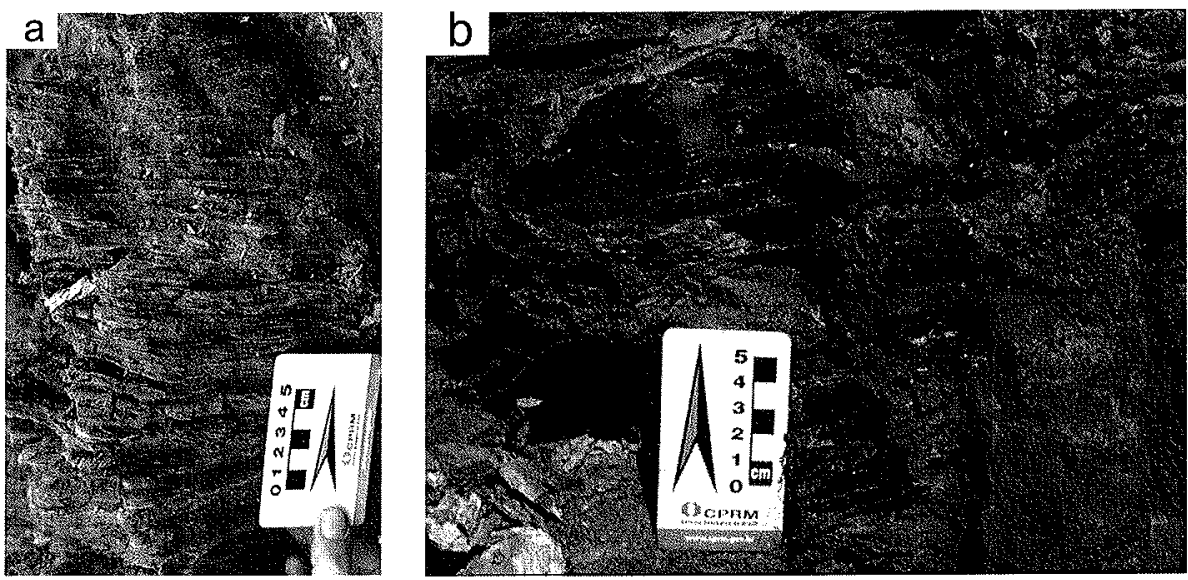

Figura 5 - Facies (a) ritmito (Rodrigo Silva) e (b) folhelho negro (Rodovia do Contorno de Ouro Preto).
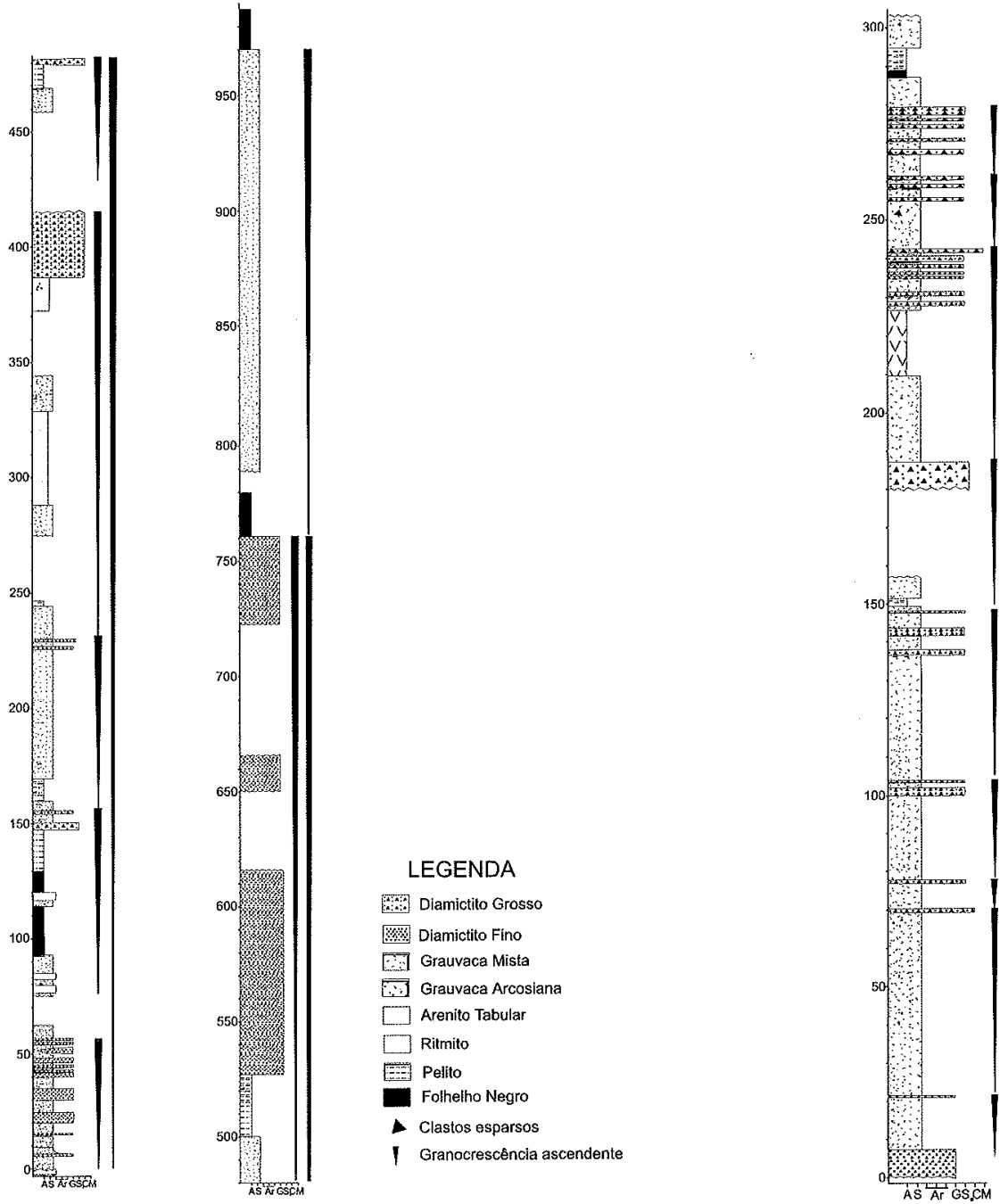

\section{LEGENDA}

Diamictito Grosso

27 Diamictito Fino

[.:- Grauvaca Mista

Eelito

Folhelho Carbonoso

Rocha vulcânica ?

- Clastos esparsos

Diamictilo Grosso

䒽 Diamictito Fino

Grauvaca Mista

.:. Grauvaca Arcosiana

$\square$ Arenito Tabular

$\square$ Rilmito

볼 Peilio

Eothelho Negro

- Clastos esparsos

Granocrescência ascendente

Granocrescência ascendente

Figura 6 - Coluna sedimentológico-estratigráfica da Rodovia do Contorno/Ouro Preto (Setor I). A- argila, S- silte, Ar-areia fina, média e grossa, $G$ - grânulo, $S_{\mathfrak{e}^{-}}$seixo, $C$ - calhau e $M$ matacão.
Figura 7 - Coluna sedimentológico-estratigráfica da Estrada Real/Ouro Preto (Setor I). A- argila, S- silte, Ar-areia fina, média e grossa, $G$ - grânulo, $S_{e^{-}}$seixo, $C$ - calhau e $M$ matacão. 


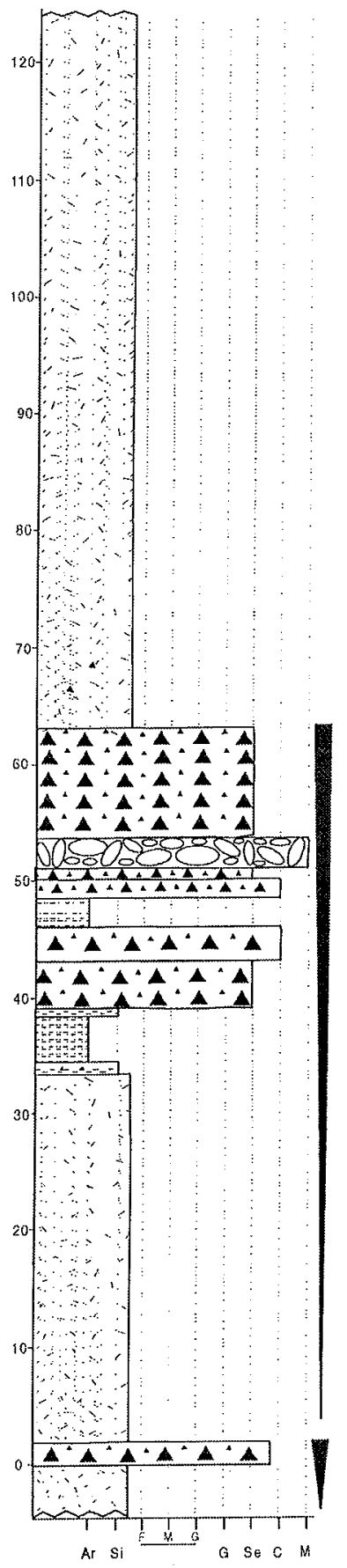

\section{LEGENDA}

Conglomerado Maciço

A. Diamictito Grosso

F. Grauvaca Mista

E Siltito

Pelito

Granocrescencia ascendente

Clastos esparsos
Figura 8 - Coluna sedimentológico-estratigráfica da Lagoa das Codornas (Setor II). Ar-argila, Si-silte, Areia $F$ - fina, $M$ média e G-grossa, G- grânulo, Se-seixo, $C$ - calhau e $M$ matacão.

A Fácies Ritmito pode ser denominada como um turbidito clássico de ambiente distal, ocorrendo no leque inferior e planície de bacia. Ritmitos com clastos (grânulos a blocos) esparsos provavelmente depositaram-se nas bordas laterais dos leques submarinos, permitindo que material mais grosso oriundo das partes proximais da bacia, atingissem porções mais profundas.

As fácies Siltito, Pelito e Folhelho Negro ocorrem como depósitos de planície de bacia, intercalados com as demais 34
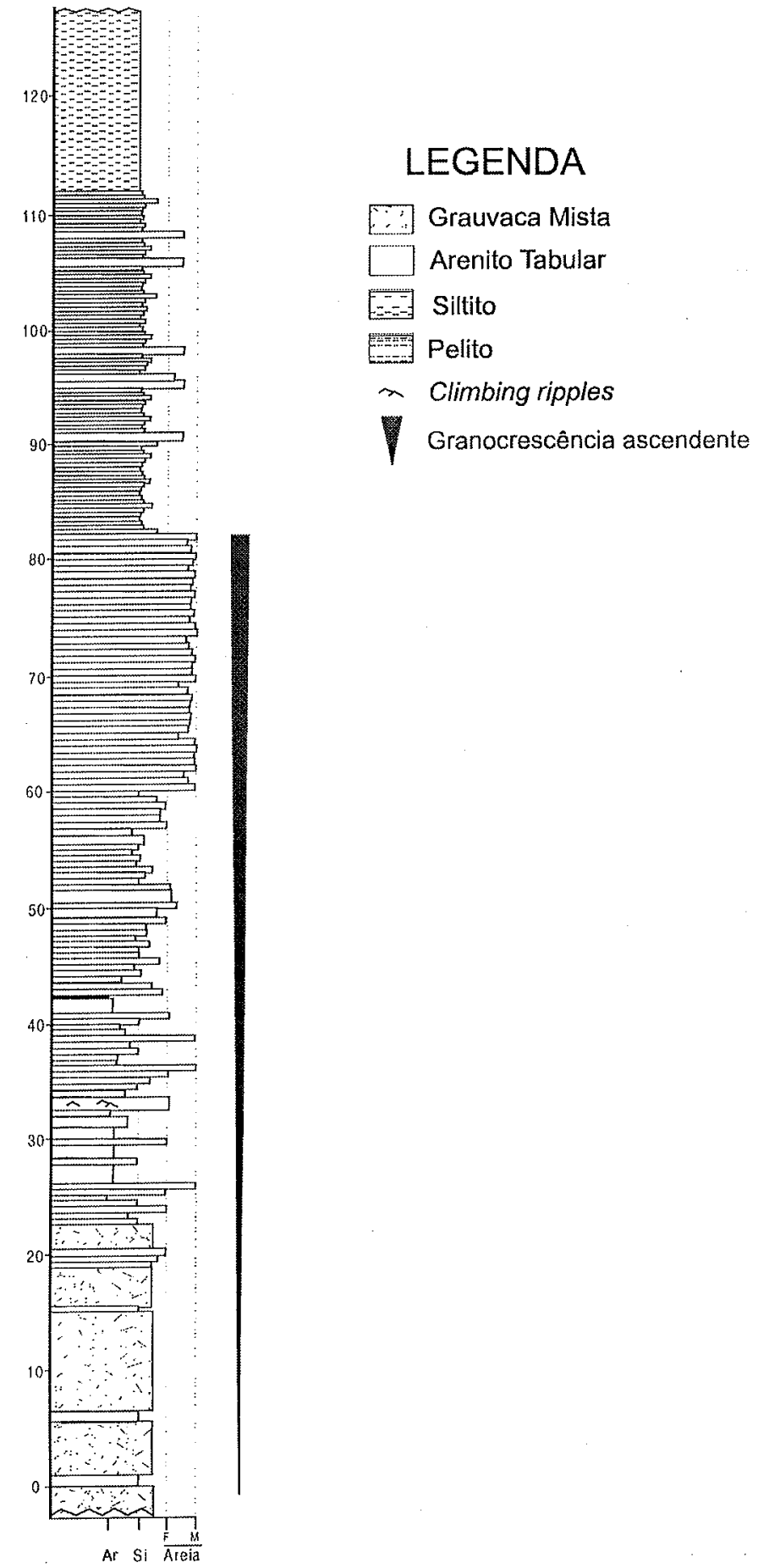

Figura 9 - Coluna sedimentológico-estratigráfica de Ibirité (Setor II). Ar-argila, Si-silte, Areia F-fina e M-média.

fácies (Fig. 12).

A BACIA SABARÁ A suíte conglomerado-diamictitograuvaca-arenito-ritmito-pelito-folhelho, pertencente ao Grupo Sabará, marca claramente uma mudança significativa do ambiente deposicional e da fonte de sedimentos em relação ao Supergrupo Minas, que teria se depositado em plataforma estável (Alkmim \& Marshak 1998). Conforme discutido a seguir 


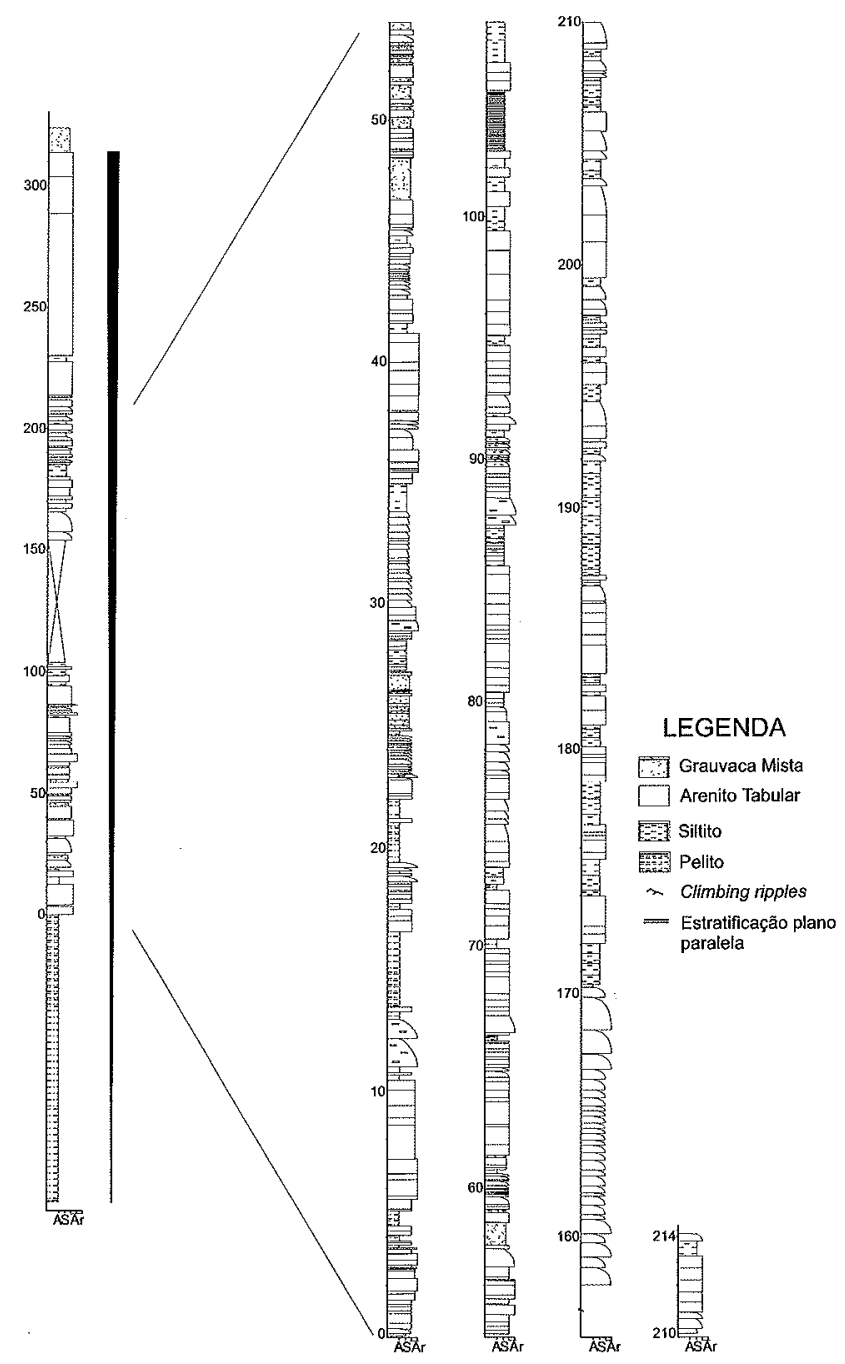

Figura 10 - Coluna sedimentológico-estratigráfica a leste de Ibirité (Setor II). A-argila, S- silte, Ar-areia fina e média.

e de acordo com sugestões da literatura (Renger et al. 1994, Machado et al. 1996, Alkmim \& Marshak 1998), este grupo representa provavelmente os depósitos uma bacia do tipo antepaís relacionada com o Evento Transamazônico.

EVIDÊNCIAS DE DEPOSIÇÃO EM BACIA DE ANTEPAÍS Evidências geocronológicas A deposição do Grupo Sabará está associada ao Evento Transamazônico, no intervalo de 2125 e $2045 \mathrm{Ma}$ (ver datações no item Contexto Regional acima), com duração de cerca de 80 m.a. (Machado e Noce 1993). O início da sedimentação Sabará marcaria a fase de inversão tectônica da bacia Minas e suas rochas o produto erosional do orógeno em construção.

Evidências petrogenéticas $\quad$ trend de distribuição das fácies do Grupo Sabará ratifica os dados da literatura que sugerem uma fonte situada a E-SE (Dorr II 1969, Barbosa 1979, Renger et al. 1994, Alkmim e Marshak 1998). Nos vários setores estudados (ver Fig. 1), há evidências que corroboram os

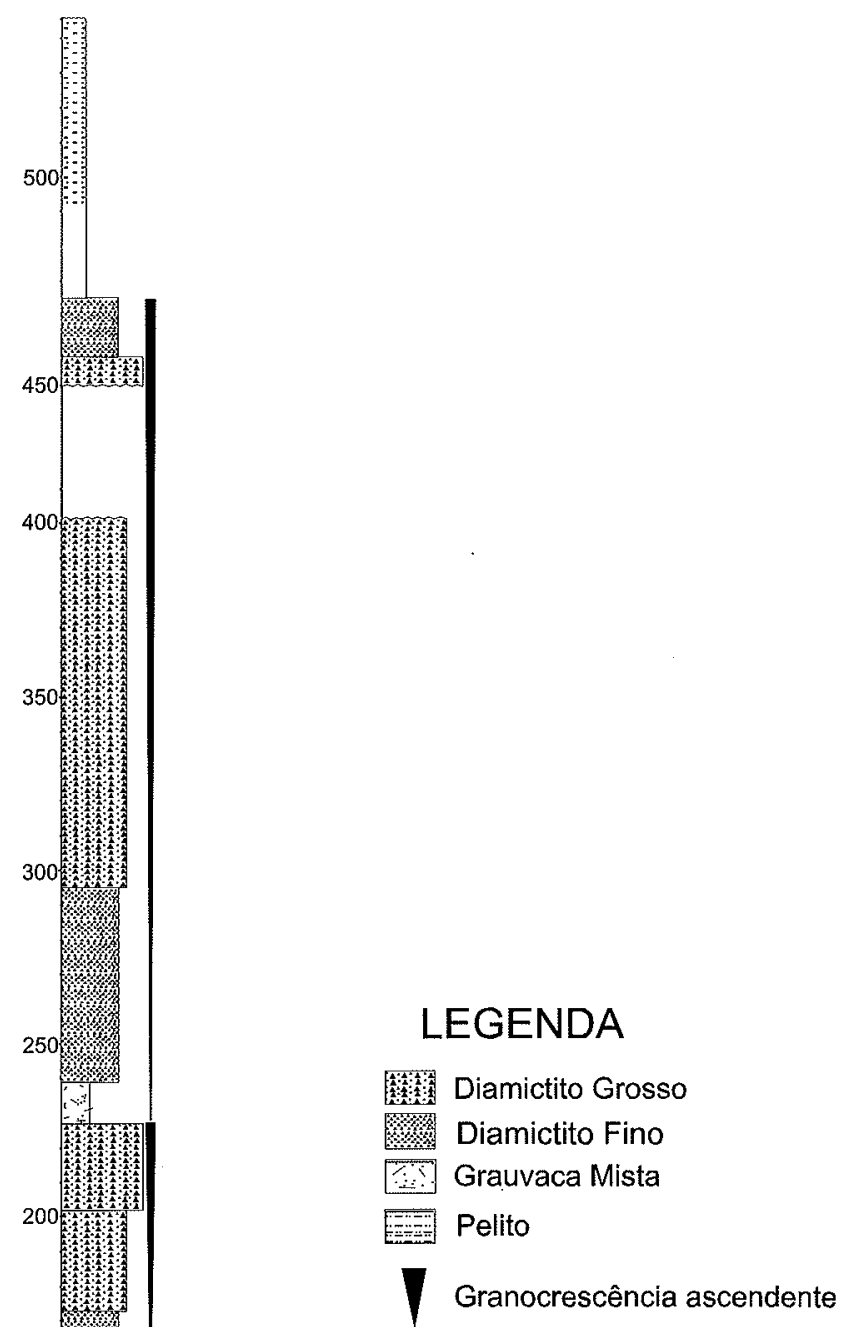

Figura II - Coluna sedinentológico-estratigráfica de Rodrigo Silva/Ouro Preto (Setor I). A- argila, S- silte, Arareia fina, média e grossa, $G$ - grânulo, $S_{e^{-}}$seixo, $C$ - calhau e $M$ - matacão. 


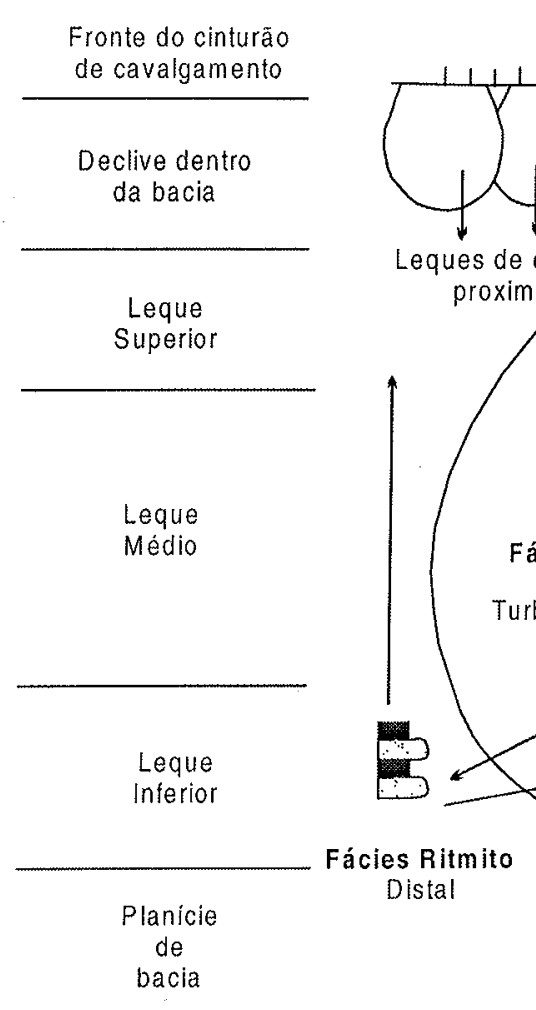

ÁREA FONTE (ORÓGENO)

Canal de alimentaçăo

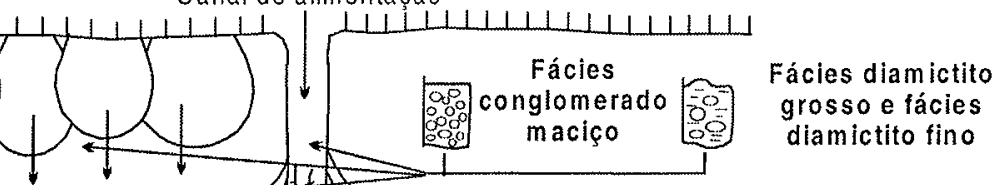

ximais
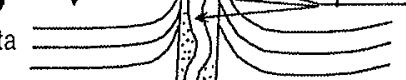

diamictito fino

Figura 12 - Modelo deposicional proposto para o Grupo Sabará.

autores citados. A suite de clastos presentes nos diamictitos e conglomerados indica retrabalhamento de seqüências supracrustais e do embasamento (Supergrupo Minas, Supergrupo Rio das Velhas e o embasamento soerguido).

No Setor I, o Grupo Sabará consiste de diamictitos, grauvacas, arenitos (pouco desenvolvidos), ritmitos, pelitos e folhelhos negros. Os diamictitos grossos, constituídos predominantemente por clastos de arenito branco e cinza, apontam para uma provável proveniência do Supergrupo Minas superior (Grupo Piracicaba). Os diamictitos finos com clastos predominantemente de embasamento e arenitos, e subordinadamente de quartzo, pelitos, pelitos dolomíticos e formação ferrífera, bem como as grauvacas mistas, sugerem uma proveniência mista. As grauvacas arcoseanas ricas em componentes feldspáticos e clastos esparsos de rochas granitóides indicam proveniência do embasamento.

A suite de rochas pertencentes ao Setor II (conglomerados, diamictitos, grauvacas, arenitos e pelitos) sugere uma proveniência de rochas supracrustais do Supergrupo Rio das Velhas e Supergrupo Minas inferior e intermediário (grupos Caraça e Itabira), evidenciada pela composição variada dos clastos (arenito branco, cinza e rosa, chert, dolomito, quartzo, pelitos e formações ferríferas). Neste setor, provavelmente não houve contribuição do embasamento, evidenciada também pela ausência de feldspatos nestas rochas.

No Setor III, a suite conglomerados-diamicitos-grauvacasarenitos-pelitos aponta para uma proveniencia semelhante ao Setor I, ou seja, rochas supracrustais do Supergrupo Minas superior (Grupo Piracicaba) e do embasamento.
Evidências geoquímicas Dados geoquímicos das rochas do Grupo Sabará (elementos maiores e terras raras) foram plotados em diagramas de proveniência. As análises de rocha total dos elementos maiores, traços e ETR das grauvacas e pelitos das regiões de Ouro Preto, Sabará e Igarapé foram obtidas de Guitarrari (1999).

Os diagramas de proveniência plotados para o Grupo Sabará apontam para uma mistura de áreas fontes. As figuras $13 \mathrm{a} \mathrm{e} \mathrm{b}$ mostram que as rochas do Grupo Sabará correspondem predominantemente ao campo de proveniência ígnea intermediária e sedimentar quartzosa, embora ocorram amostras em todos os campos, indicando compartimentação da área fonte.

Os dados foram também plotados em diagramas de proveniência por ambiente tectônico obtidos em Rollinson (1993). A Fig. $13 \mathrm{c}$ mostra que as rochas da região de Ibirité são derivadas predominantemente de uma margem continental ativa e arco magmático continental, enquanto na Fig. 13d, estas mesmas rochas correspondem predominantemente ao campo de margem continental ativa. Apesar de algumas amostras caírem no campo de margem passiva, a proveniência provável para as rochas do Grupo Sabará é de margem continental ativa/arco magmático continental. Os gráficos das figuras $13 \mathrm{e}$ e f mostram grande dispersão, sugerindo uma proveniência mista.

De maneira geral, os diagramas litoquímicos indicam uma proveniência de margem continental ativa/arco magmático continental, sugerindo, em conjunto com os dados macro e microscópicos, ter sido provavelmente um orógeno a área fonte do Grupo Sabará. 

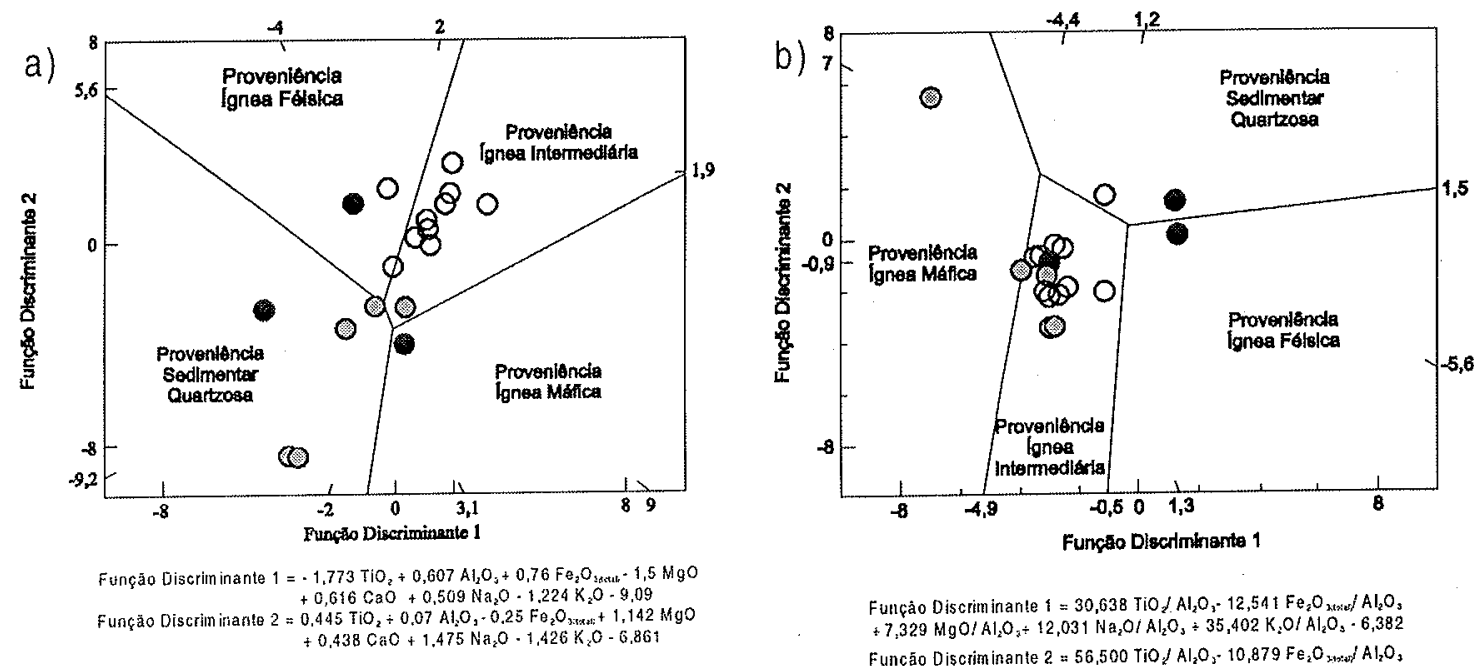

Funçâo Discriminante $1=30,638 \mathrm{TiO} / \mathrm{Al}, \mathrm{O}, \cdot 12,541 \mathrm{Fe}, \mathrm{O}_{2, t a t} / \mathrm{Al}_{2} \mathrm{O}$ $+7,329 \mathrm{MgO} / \mathrm{Al}_{2} \mathrm{O}_{3}+12,031 \mathrm{Na}, \mathrm{O} / \mathrm{Al}_{2} \mathrm{O}_{3}+35,402 \mathrm{~K}_{2} \mathrm{O} / \mathrm{Al}_{2} \mathrm{O}_{3} \cdot 6,382$ Funçáo Discriminante 2 = $56,500 \mathrm{TiO}_{2} / \mathrm{Al}_{2} \mathrm{O}, 10,879 \mathrm{Fe}_{2} \mathrm{O}_{3 \rightarrow \infty} / \mathrm{Al}_{2} \mathrm{O}$,

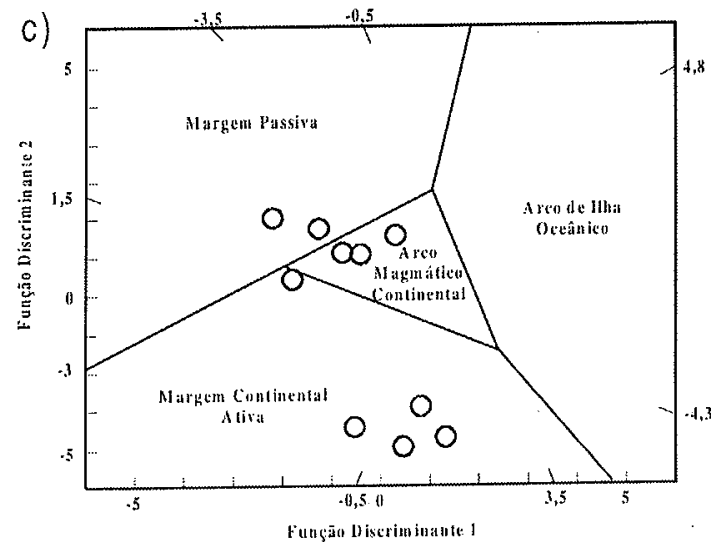

d)

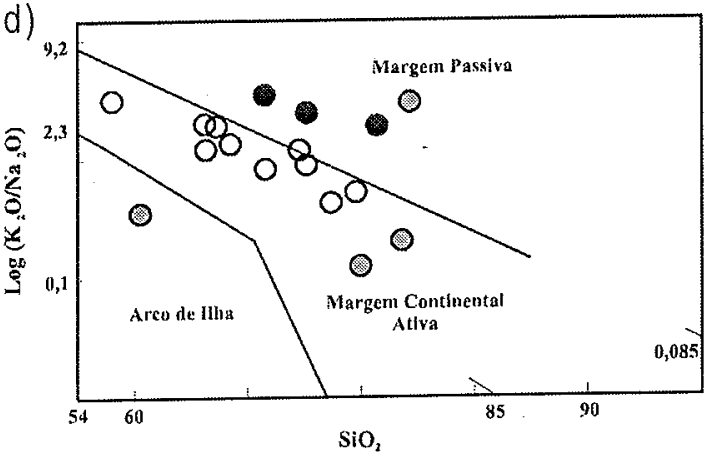

f)

Furigate Discriminanle $1=-0,0447 \mathrm{SiO}_{2}=0,972 \mathrm{TiO}_{2}+0,008 \mathrm{Al}_{2} \mathrm{O}_{2} \cdot 0,267 \mathrm{Fe}_{2} \mathrm{O}$ $+0,208 \mathrm{FeO} \cdot 3,082 \mathrm{MnO}+0,140 \mathrm{MgO}+0,195 \mathrm{C} 0$
$+0,719 \mathrm{Na}, 0.0,032 \mathrm{~K}, \mathrm{O}+7,510 \mathrm{P}, \mathrm{O}=0,303$ $0.421 \mathrm{SiO}_{2}+1.988 \mathrm{FiO}_{2}-0.520 \mathrm{Al}_{2} \mathrm{O}_{3}-0.551 \mathrm{Fe}_{2} \mathrm{O}_{3}$ $-1.610 \mathrm{FoO}_{0}+2.720 \mathrm{MnO}+0,881 \mathrm{MgO}-0.907 \mathrm{CaO}_{\mathrm{aO}}$
$0.177 \mathrm{Na}_{2} \mathrm{O}+1,840 \mathrm{~K}_{2} \mathrm{O}+7,244 \mathrm{P}_{2} \mathrm{O}_{3}+43,57$
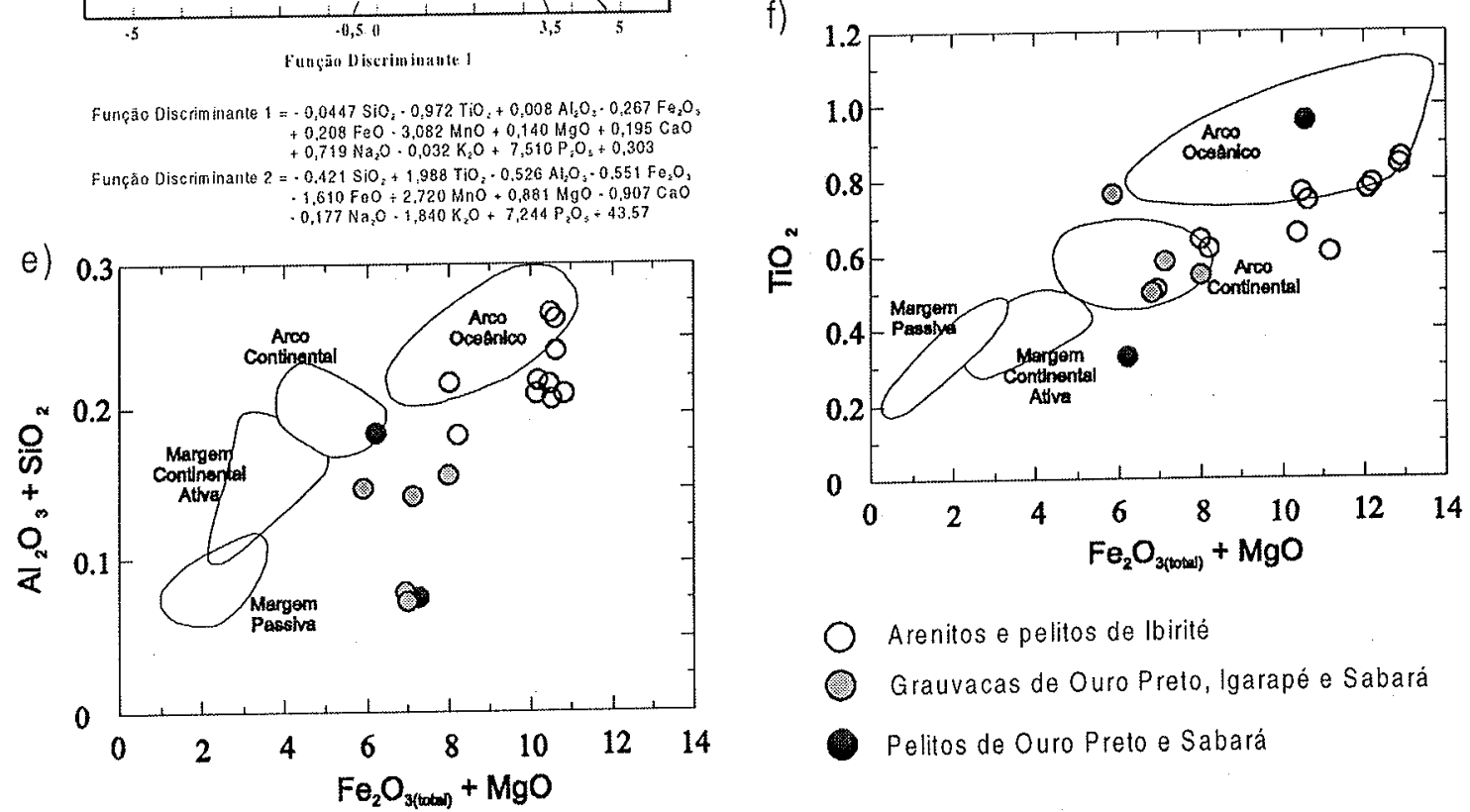

Arenitos e pelitos de Ibirité

-) Grauvacas de Ouro Preto, Igarapé e Sabará

- Pelitos de Ouro Preto e Sabará

Figura 13 - (a) - Diagrama de função discriminante para proveniência das suites arenito-pelito usando elementos maiores. Campos para proveniência ígnea máfica, intermediária e félsica e sedimentar quartzosa. (b) - Diagrama de função discriminante para proveniência das suites arenito-pelito usando razões de elementos maiores. Campos para proveniência ígnea máfica, intermediária e félsica e sedimentar quartzosa. (c) - Diagrama de função discriminante para arenito mostrando campos de arenito de margem continental passiva, arco de ilha oceanico, arco magmático continental e margem continental ativa. (d) - Diagrama discriminante log $\left(\mathrm{K}_{2} \mathrm{O} / \mathrm{Na}_{2} \mathrm{O}\right)$ vs $\mathrm{SiO}_{2}$ para suites arenito-pelito, mostrando campos para margem continental passiva, margem continental ativa e arco de ilha. (e)-Diagrama discriminante para arenitos, baseado em gráfico bivariante, para TiO $\mathrm{O}_{2}$ vs $\left(\mathrm{Fe}_{2} \mathrm{O}_{3(t o t a l)}+\mathrm{MgO}\right)$ e $(f)$ - gráfico bivariante para $\mathrm{Al}_{2} \mathrm{O}_{3} / \mathrm{SiO}_{2}$ vs $\left(\mathrm{Fe}_{2} \mathrm{O}_{3(t \mathrm{tut})}+\mathrm{MgO}\right)$. Os campos são arco de ilha oceânico, arco continental, margem continental ativa e margem continental passiva (modificado de Rollinson 1993). 


\section{A bacia de antepaís paleoproterozóica Sabará, Quadrilátero Ferrifero, Minas Gerais}

As rochas do Grupo Sabará, segundo Guitarrari (1999), possuem fracionamento similares e fortes de ETRL (elementos terras raras de número atômico baixo), mostrado pela razão $\mathrm{La}_{\mathrm{N}} / \mathrm{Yb}_{\mathrm{N}}=$ $5,96-11,52$. As metagrauvacas basais mostram $\mathrm{Nm}$ fracionamento em ETRP (elementos terras raras de número atômico alto) de $\mathrm{Tb}_{\mathrm{N}} / \mathrm{Yb}_{\mathrm{N}}=1,72$, enquanto os pelitos intermediários mostram um padrão enriquecido de $\mathrm{Tb}_{\mathrm{N}} / \mathrm{Yb}_{\mathrm{N}}=0,84$, indicando concentração de minerais pesados como zircão e monazita. O gráfico de ETR Condrito-Normalizado (Fig. 14) mostra uma anomalia de Eu negativa e um enriquecimentos em elementos leves para os pelitos, correspondendo, segundo Taylor e McLennan (1985), a ambiente de margem passiva, enquanto as grauvacas não apresentam anomalia de Eu e são correspondentes à ambiente de margem continental ativa/arco magmático continental. As grauvacas/pelitos basais, segundo Guitarrari (1999), não apresentam anomalia de $\mathrm{Eu}\left(\mathrm{Eu}_{\mathrm{N}} / \mathrm{Eu}^{*}=\right.$ 1,0 ), enquanto as intermediárias apresentam anomalia negativa de $\mathrm{Eu}\left(\mathrm{Eu}_{\mathrm{N}} / \mathrm{Eu}^{*}=0,45\right)$, característica de rochas sedimentares pós-arqueanas (Taylor e McLennan 1985). A presença ou ausência de anomalia pode indicar características diferentes herdadas de porções distintas da área fonte. Entretanto, a evolução de grauvacas/pelitos basais sem anomalia de Eu (proveniência de arco magmático continental) para grauvacas intermediárias com anomalia negativa (proveniência de margem passiva) pode ser interpretada como uma evolução de bacia de antepaís retroarco para colisional.

Nas figuras 15 a e b observa-se que as rochas no Grupo Sabará estão plotadas no campo B (arco magmático continental). Todos estes diagramas são compatíveis com depósitos de uma bacia de antepaís, pois mostram área fonte de natureza mista e complexa, típica de um orógeno.

Evidências sedimentológico-estratigráficas As características, distribuição e arranjo das fácies (Figs. 6, 7, 8, 9, 10, 11) e a presença de fluxos de detritos, fluxos de massa e correntes de turbidez no Grupo Sabará são indicativos de ambiente de leques submarinos (Fig. 16). O arranjo estratigráfico em sucessivos ciclos em CU mostra que a bacia foi controlada por processos extrabacinais (geração de espaço e suprimento

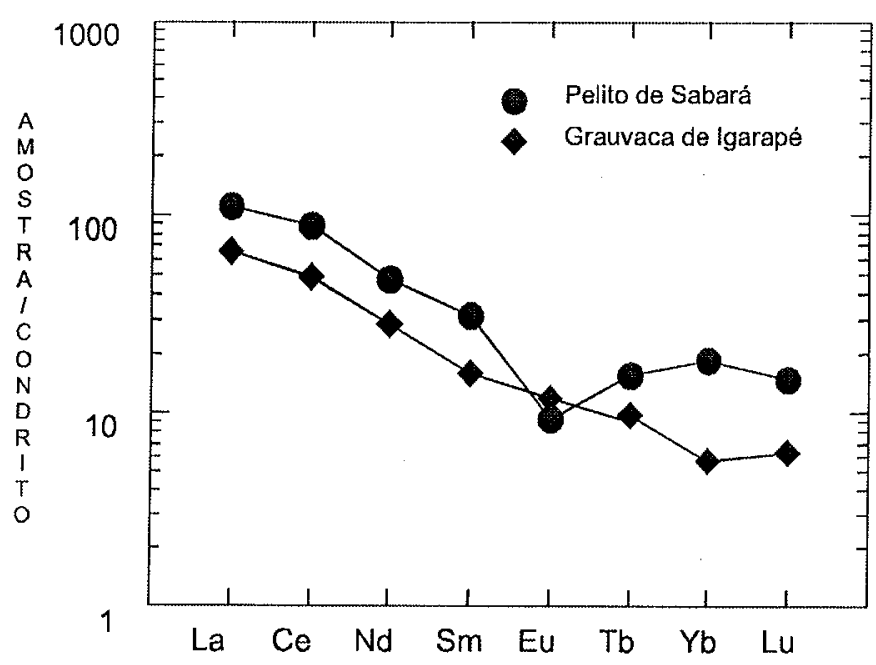

Figura 14 - Padrão ETR para as rochas do Grupo Sabará. sedimentar). A ocorrência de depósitos pelíticos sob depósitos grosseiros em uma sucessão sedimentar em CU é um excelente indicador de atividade tectônica episódica (Blair e Bilodeau 1988), ou seja, geração "instantânea" de espaço e relevo diferencial área fonte/bacia por evento de cavalgamento no orógeno e resposta flexural na bacia, seguido por progressivo preenchimento do espaço de acomodação durante períodos de quiescência tectônica.

O arcabouço estratigráfico do Grupo Sabará encontra-se organizado em sucessões em CU. Os dados em algumas colunas (p.ex., Figs. 6 e 10) mostram sucessões maiores na escala de centenas de metros, englobando sucessões hierarquicamente
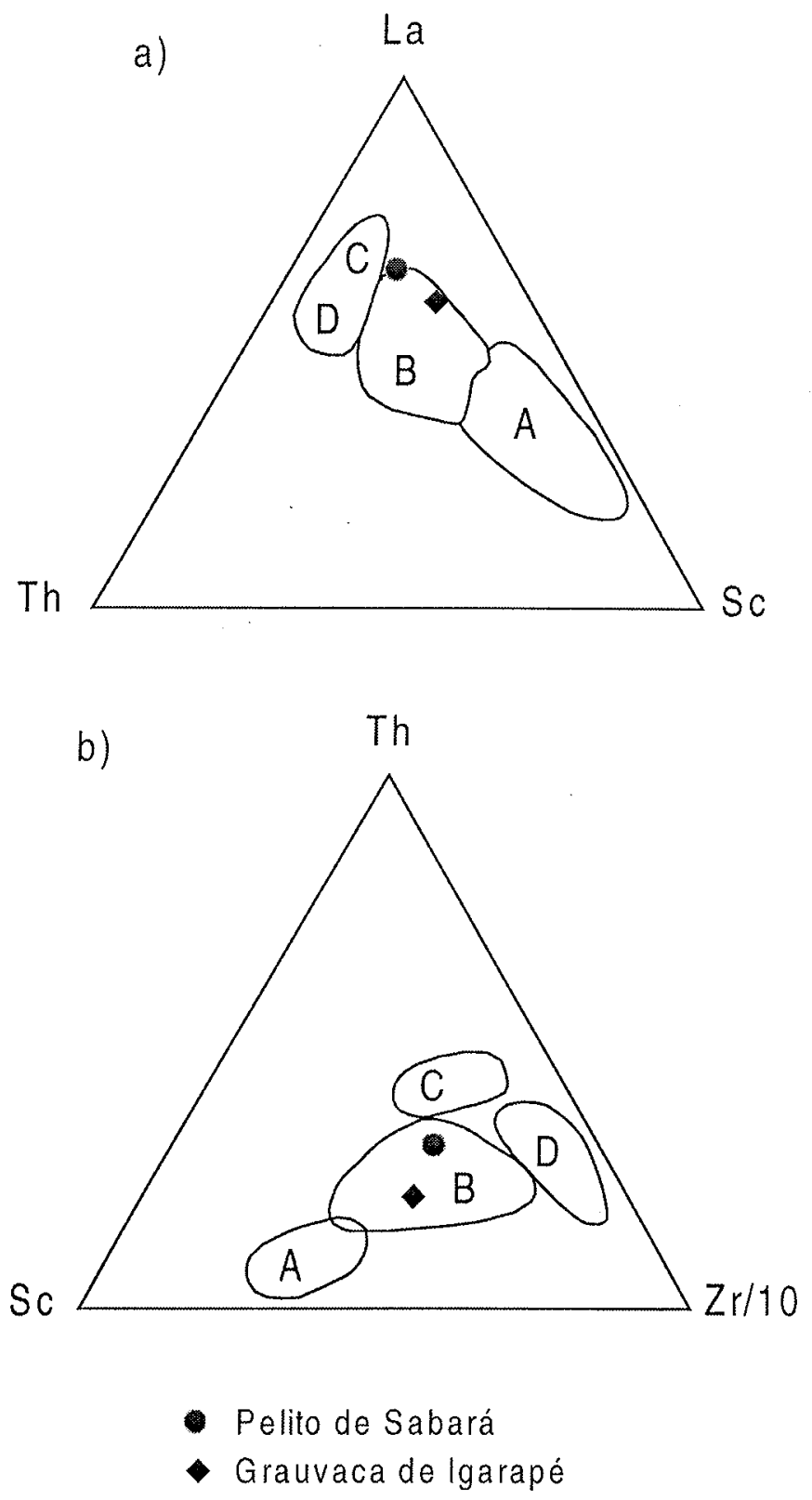

Figura 15 - (a) - Diagrama discriminante La-Th-Sc para grauvacas; (b) - Diagrama discriminante $T h-S c-Z r / 10$ para grauvacas. Os campos são: $A$, arco de ilha ocếnico; $B$ arco magmático continental; $C$, margem continental ativa; $D$, margem passiva (modificado de Rollinson 1993). 

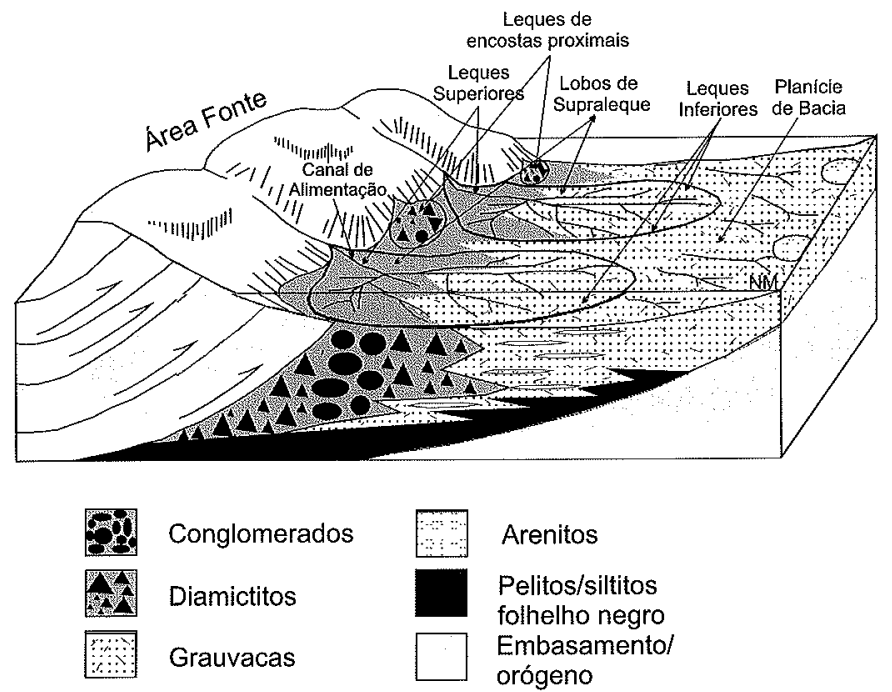

Figura 16 - Figura esquemática do ambiente deposicional do Grupo Sabará.

inferiores de espessura métrica a decamétrica. Este arranjo indica que o padrão da sedimentação do Grupo Sabará foi marcado por altas taxas iniciais de geração de espaço de acomodação, em relação à taxa de suprimento sedimentar para a bacia, evidenciado pela deposição de fácies pelíticas. A presença de turbiditos de baixa densidade e/ou grauvacas mostra o início da progradação clástica, cuja evolução de condições distais para proximais foi marcada pela presença de turbiditos e/ou grauvacas mais densos. A deposição de conglomerados e diamictitos subsequente mostra que as taxas de suprimento sedimentar superaram a geração de espaço de acomodação. A superposição de fácies grossas sobre fácies distais evidencia a progradação dos lobos deposicionais com a migração progressiva do cinturão de cavalgamento/dobramento (Jordan 1995). As sucessões em CU em diferentes hierarquias significam a superposição de pulsos de subsidência episódica de diferentes magnitudes.

TIPO DE BACIA DE ANTEPAÍS A localização geográfica dos depósitos do Grupo Sabará em relação ao embasamento e supracrustais do Quadrilátero Ferrífero, os tipos de rochas e a variação composicional dos clastos e fragmentos líticos presentes nas rochas dos diferentes setores do Grupo Sabará apontam para diferentes áreas fontes, sugerindo uma bacia de antepaís compartimentada (Fig. 17). Com base nisto, a Bacia de Antepaís Sabará foi dividida em três sub-bacias: Sub-bacia Antônio Pereira-Ouro Preto-Mariana-Rodrigo Silva (SB1), Sub-bacia Lagoa das Codornas (SB2) e Sub-bacia Sabará-Belo Horizonte-Ibirité-Fernão Dias (SB3) (Fig. 17).

A Sub-bacia Antônio Pereira-Ouro Preto-Mariana-Rodrigo Silva é constituída pelas litofácies diamictito grosso, diamictito fino, grauvaca mista, graucava arcoseana, ritmitos, pelitos e folhelho negro. Nesta sub-bacia, predominam os processos de fluxos de massa, indicando proximalidade em relação aos frontes de cavalgamento e da área fonte. Trata-se provavelmente de um compartimento intermontano do foreland Sabará, do tipo piggy-back basin.

A Sub-bacia Lagoa das Codornas, também intermontana, é constituída pelas litofácies conglomerado, diamictito grosso, arenito, siltito e pelito. Os conglomerados e diamictitos da Subbacia Lagoa das Codornas, apesar desta sub-bacia encontrar-se próxima ao Complexo do Bação (Fig. 17), não apresentam clastos de embasamento. Isto sugere um fornecimento proximal em relação à bacia, com as rochas supracrustais dos supergrupos Rio das Velhas e Minas.

A Sub-bacia Sabará-Ibirité-Fernão Dias, periférica ao orógeno, é constituída pelas litofácies conglomerado, diamictito grosso, diamictito fino, grauvaca, arenito, siltito e pelito. Nesta sub-bacia os turbiditos são mais desenvolvidos, indicando, a preservação de um ambiente mais profundo e/ou distal (Fig. 17). As fácies mais grossas ocorrem de forma esparsa, indicando que as fácies progradacionais finais não foram preservadas do soerguimento final por compensação isostática (Jordan 1995) e posterior erosão.

CONTEXTO GEOTECTÔNICO DO FORELAND SABARÁ A porção sul do Cráton do São Francisco é formada por uma plataforma estabilizada a $2,6 \mathrm{Ga}$ (Noce et al. 1998), constituída por gnaisses migmatizados, greenstone belts, plútons de granitóides e intrusões máficas e máficas-ultramáficas. Durante a Orogenia Transamazônica $(2,16-2,0 \mathrm{Ga})$, um cinturão colisional em forma de arco, denominado de Cinturão Mineiro (Teixeira et al. 2000), desenvolveu-se nas margens desta plataforma arqueana, formando plútons de granitóides, diques máficos e depósitos do tipo flysh.

Segundo Alkmim e Marshak (1998), o cinturão de cavalgamento/dobramentos (Cinturão Mineiro) foi criado em resposta a uma contração com vergência para NW, relacionada com a acresção de um arco de ilha e/ou terrenos exóticos nas margens leste e sudeste do Cráton do São Francisco. Neste evento, pode ter ocorrido o consumo de crosta oceânica e geração de tonalitos de origem mantélica e trondhjenitos $(2,162-2,124$ Ga), seguido por intrusões de granitos crustais sin a póscolisionais (Teixeira et al. 2000). A evolução da bacia Sabará ocorreu durante esta época, com proveniência da erosão dos depósitos arqueanos e paleoproterozóicos do Cinturão Mineiro.

Conclusões O Grupo Sabará ocorre no Sinclinal Dom Bosco (Setor I, Fig. 1), Sinclinal Moeda (Setor II) e na Serra do Curral (Setor III), além de outras ocorrências sem afloramentos adequados para os propósitos deste trabalho (sinclinais Gandarela e Santa Rita). Levantamentos sedimentológicoestratigráficos permitiram a identificação das seguintes fácies: conglomerado maciço (fluxo de detritos), diamictito grosso (fluxo de detritos), diamictito fino (fluxo de detritos), grauvaca mista (fluxo de massa), grauvaca arcosiana (fluxo de massa), arenito tabular (correntes de turbidez), ritmito (correntes de turbidez), siltito (correntes de turbidez), pelito (deposição da suspensão) e folhelho negro (deposição da suspensão). Estas fácies ocorrem, de maneira geral, organizadas em sucessões em $\mathrm{CU}$, representando geração episódica de espaço e relevo diferencial área fonte/bacia por evento de cavalgamento no orógeno e resposta flexural na bacia, seguido por progressivo preenchimento do espaço de acomodação durante períodos de quiescência tectônica.

O modelo deposicional proposto para o Grupo Sabará é de leque submarino com planície de bacia e leques de encosta proximais. Este modelo é constituído por canal(is) de alimentação, declive da bacia, leque superior, leque médio, leque inferior e planície de bacia. As fácies Conglomerado Maciço, 
SE

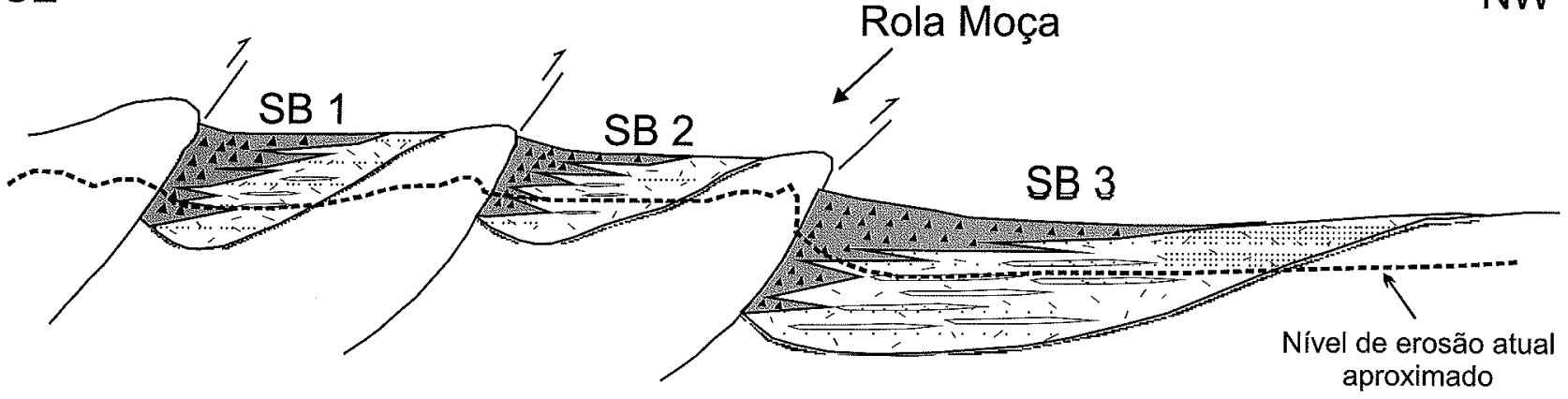

SB 1: Sub-bacia Antônio Pereira-Mariana-Ouro Preto-Rodrigo Silva

SB 2: Sub-bacia Lagoa das Codornas

SB 3: Sub-bacia Sabará-Belo Horizonte-Ibirité-Fernão Dias

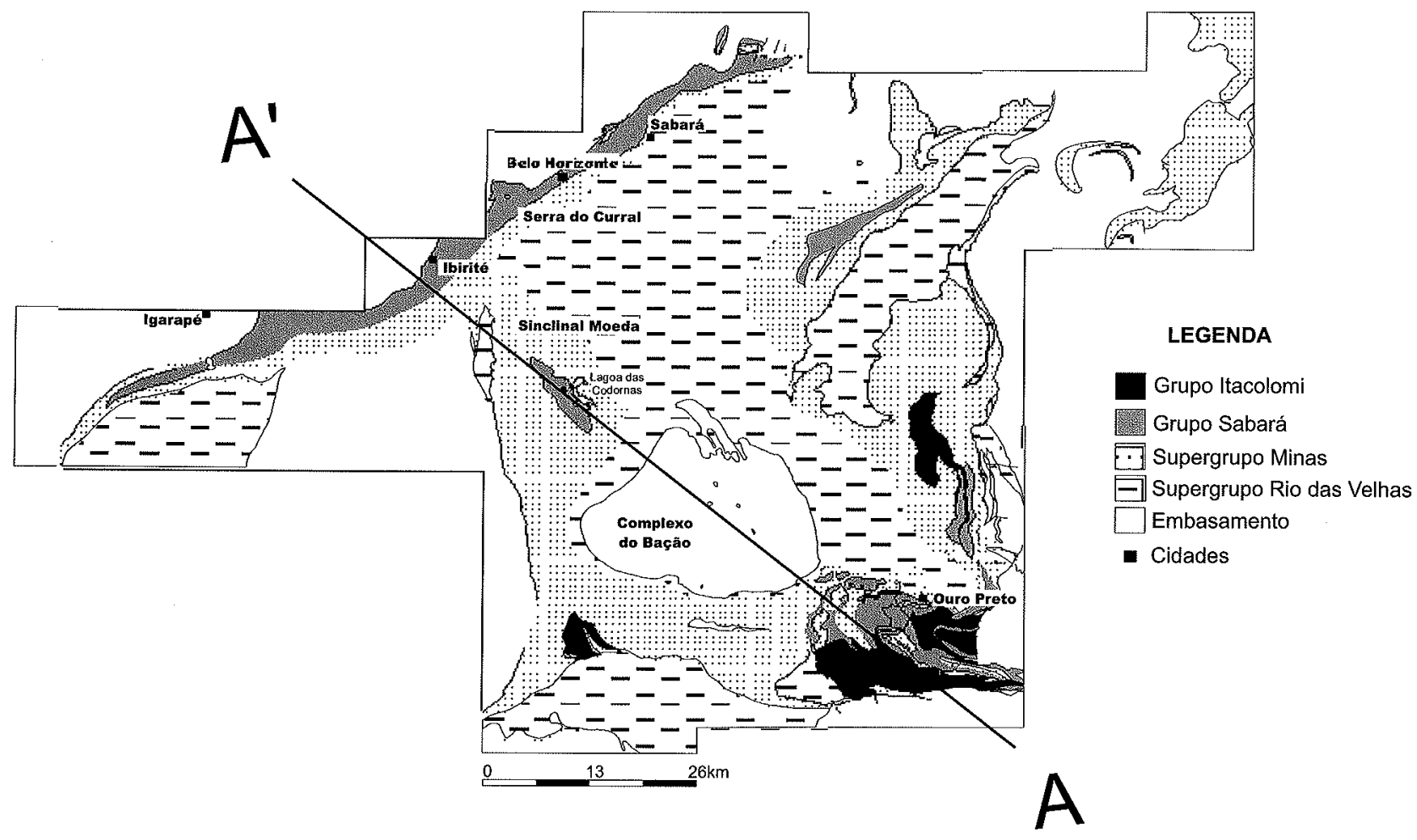

Figura 17 - Seção esquemática da bacia de antepaís compartimentada Sabará (modificada de Allen e Allen 1990) e sua localização esquemática no Quadrilátero Ferrifero (Mapa Geológico modificado de Dorr II 1963). 
Diamictito Grosso e Diamictito Fino ocorrem nos leques de encosta proximais e na parte interna dos canais de alimentação. As fácies Grauvaca Arcoseana e Grauvaca Mista estão presentes nos lobos e nos interlobos, ocorrendo em todas as partes do leque submarino e na planície de bacia. Os turbiditos ocorrem nas porções mais distais dos lobos de supraleque e nos leques inferiores. A Fácies Ritmito (turbidito de ambiente distal) ocorre no leque inferior, na planície de bacia e nas bordas laterais dos leques submarinos. As fácies Siltito, Pelito e Folhelho Negro ocorrem como depósitos de planície de bacia, intercalados com as demais fácies.

O Grupo Sabará representa os depósitos uma bacia do tipo antepaís relacionada ao Evento Transamazônico. Os clastos presentes nos diamictitos e conglomerados indicam o retrabalhamento de seqüencias supracrustais e do embasamento (Supergrupo Minas, Supergrupo Rio das Velhas e o embasamento soerguido). Os diagramas de proveniência plotados para o Grupo Sabará apontam para uma mistura de áreasfonte, predominando a proveniência ígnea intermediária $\mathrm{e}$ sedimentar quartzosa, embora proveniências ígnea félsica e ígnea máfica também ocorram, indicando compartimentação da área fonte. Os diagramas de proveniência por ambiente tectônico indicam uma proveniência de margem continental ativa/arco magmático continental. Estes dados em conjunto com os dados macro e microscópicos sugerem uma área fonte orogênica para o Grupo Sabará. O gráfico de ETR mostra uma anomalia de Eu negativa e um enriquecimento em elementos leves para os pelitos correspondendo a ambiente de margem passiva (Taylor e McLennan 1985), enquanto as grauvacas não apresentam anomalia de Eu e são correspondentes à ambiente de margem continental ativa/arco magmático continental. A evolução de grauvacas/pelitos basais sem anomalia de Eu (proveniência de arco magmático continental) para grauvacas intermediárias com anomalia negativa (proveniência de margem passiva) presentes nestas rochas pode representar uma evolu- ção de bacia de antepaís retroarco para colisional.

O Grupo Sabará representa provavelmente uma bacia de antepaís compartimentada, formada durante a deformação, soerguimento e erosão dos depósitos arqueanos e paleoproterozóicos do Cinturão Mineiro, de idade transamazônica. Uma bacia do tipo compartimentada foi sugerida devido à localização geográfica dos depósitos do Grupo Sabará em relação ao embasamento e supracrustais do Quadrilátero Ferrífero, bem como aos tipos de rochas e à variação composicional dos clastos e fragmentos líticos presentes nos diferentes setores estudados. A compartimentação da bacia, atestada principalmente nos ruditos que indicam proveniência local, aparentemente se conflita com a proveniência homogênea e mais distal sugerida pelos dados geoquímicos oriundos dos pelitos e grauvacas. Entretanto, o posicionamento estratigráfico superior dos ruditos indica que a compartimentação da bacia se deu nos seus estágios mais tardios de sua evolução, provavelmente no estágio colisional, quando os compartimentos intermontanos teriam sido individualizados.

Agradecimentos Este trabalho é uma síntese da dissertação de mestrado de LAR, desenvolvida no DEGEO/EM/UFOP sob a orientação de MAMN, co-orientação de NSG e IE e colaboração de HJE. Os autores são gratos a Fernando Alkmim do DEGEO/EM/UFOP pela indicação de vários afloramentos e a A.C. Pedrosa-Soares do IGC/UFMG pela ajuda na litoquímica. À Capes pela concessão de bolsa de mestrado a LAR. Ao CNPq pela Bolsa de Produtividade em Pesquisa a MAMN. Este trabalho foi quase inteiramente desenvolvido com recursos financeiros próprios de LAR e MAMN, exceto alguns dias de campo na região de Ouro Preto/Rodrigo Silva realizados em conjunto com alunos da disciplina Trabalho Geológico do DEGEO/EM/UFOP, ao qual prestamos nossos agradecimentos. Aos revisores da $R B G$ pelas valiosas sugestões.

\section{Referências}

Allen P.A. \& Allen J.R.L. 1990. Basin Analysis. Oxford, Blackwell, 426p.

Alkmim F.F. 1987. Modelo deposicional para a sequência de metassedimentos da Serra de Ouro Branco, Quadrilátero Ferrífero, Minas Gerais. In: Bol. da Soc. Bras. Geol., Núcleo Minas Gerais, 6:47-68.

Alkmim F.F. \& Marshak S. 1998. Transamazonian Orogeny in the Southern São Francisco Craton Region, Minas Gerais, Brazil: evidence for Paleoproterozoic collision and collapse in the Quadrilátero Ferrífero. Precambrian Res., 90:29-58.

Babinki M., Chemale F.Jr., Van Schmus W.R. 1991. Geogronologia $\mathrm{Pb} / \mathrm{Pb}$ em rochas carbonáticas do Supergrupo Minas, Quadrilátero Ferrífero, Minas Gerais, Brasil. In: Anais III Cong. Bras. Geoquímica, São Paulo, Soc. Bras. de Geoquímica, Resumos, 2:682-631.

Barbosa A.L.M. 1968. Contribuições recentes à geologia do Quadrilátero Ferrífero. In: SBG-MG reimpressão (1983), UFOP/ Depto de Geologia, 44p.

Barbosa A.L.M. 1979. Variações de fácies na Série Minas. Bol. da Soc. Bras. Geol., Núcleo Minas Gerais, 1:89-100.

Blair T.C. \& Bilodeau W.L. 1988. Development of tectonic cyclothems in rift pull-apart and foreland basins: sedimentary response to episodic tectonism. Geology, 16:517-520

Carneiro M.A., Teixeira W., Carvalho Júnior I.M., Fernandes
R.A. 1998. Ensialic tectonic setting of the Archean Rio das Velhas Greenstone Belt: $\mathrm{Nd}$ and $\mathrm{Pb}$ isotopic evidence from the Bonfim Metamorphic Complex, Quadrilátero Ferrífero, Brazil. Rev. Bras. Geoc., 28:189-200.

Chemale F.Jr., Rosière C.A., Endo I. 1994. The tectonic evolution of the Quadrilátero Ferrifero, Minas Gerais, Brazil. Precambrian Res., 65:25-24.

Da Silva H.T.F. 1993. Flooding surfaces, depositional elements and accumulations rates - characteristics of the Lower Cretaceous in the Reconcavo Basin northeast Brazil. Univ. of Texas, Tese de Doutorado, 312 p (inédito).

Dorr J.V.N. II 1963. Mapa Geológico do Quadrilátero Ferrífero, 1:150.000, DNPM/USGS.

Dorr J.V.N. II 1969. Physiographic, stratigraphic and structural development of the Quadrilátero Ferrifero, Minas Gerais, Brazil. U.S. Geol. Surv. Prof. Paper 641-A U.S.G.S., 110 p.

Gair J.E. 1958. The Sabará Formation. In: Symposium on Stratigraphy of Minas Series in the Quadrilátero Ferrifero, Minas Gerais, Brazil. Boletim da Sociedade Brasileira de Geologia, São Paulo 7:68-69.

Guitarrari M.M. 1999. Petrografia e geoquímica dos metassedimentos turbidíticos dos grupos Nova Lima e Sabará no Quadrilátero Ferrífero, Minas Gerais. UNICAMP Campinas/São Paulo, Dissertação de 
Mestrado 101 p (inédito).

Herz N. 1970. Gnaissic and Igneous Rocks of the Quadrilatero Ferrífero, Minas Gerais, Brazil. U.S. Geol. Surv. Prof. Pap. $641-B, 58$ p.

Jordan T.E. 1995. Retroarc foreland and related basins. In: C. J. Busby \& R. V. Ingersoll (eds.) Tectonics of Sedimentary Basins. Blackwell Science, 331-362.

Machado N., Noce C.M., Oliveira O.A.B., Ladeira E.A. 1989. Evolução geológica do Quadrilátero Ferrífero no Arqueano e Proterozóico Inferior com base em Geogronologia U-Pb. In: Anais do V Simpósio de Geologia de Minas Gerais, Belo Horizonte. Bol. da Soc. Bras. Geol., Núcleo Minas Gerais, 10:1-4.

Machado N., Noce C.M., Ladeira E.A., Belo De Oliveira O. 1992. U-Pb Geochronology of Archean magmatism and Proterozoic metamorphism in the Quadrilátero Ferrífero, southern São Francisco craton, Brazil. Geol. Soc. Am. Bull., 104:1221-1227.

Machado N. \& Noce C.M. 1993. A evolução do Setor Sul do Cráton São Francisco entre 3,12 e $0,5 \mathrm{Ga}$, baseada em Geogronologia U-Pb. In: Simp. Cráton São Francisco 2, Salvador, Anais, SBG-BA SE/SBG, p 100-102.

Machado N., Schrank A, Noce C.M., Gauthier G. 1996. Ages of detrital zircon from Archean-Paleoproterozoic sequences: implications for Greenstone Belt setting and evolution of a Transamazonian foreland basin in Quadrilátero Ferrífero, southeastern Brazil. Earth Planet. Sci. Lett., 141:259-276.

Marshak S. \& Alkmim F.F. 1989. Proterozoic contraction/ extension tectonics of the southern São Francisco region, Minas Gerais, Brazil. Tectonics, 8:555-571.

Mutti E. \& Ricci Lucchi F. 1972. Turbidite of the northern Apennines: introduction to facies analysis. Intern. Geol. Rev., 20:125-166.

Normark W.R. 1978. Fan valleys, channels and depositional lobes on modern submarine fans: characters for recognition of sandy turbidite environments. AAPG Bull. 62:912-931.

Noce C.M. 1995. Geocronologia dos eventos magmáticos, sedimentares e metamórficos na região do Quadrilátero
Ferrífero. Instituto de Geociências Universidade de São Paulo, Brasil, Tese de Doutorado, 127 p (inédito).

Noce C.M., Machado N., Teixeira W. 1998. U-Pb Geochronology of Gnaisses and Granitoids in Quadrilátero Ferrífero (Southern São Francisco Craton): age constraints for Archean and Paleoproterozoic magmatism and metamorphism. Rev. Bras. Geoc., 28:95-102.

Renger F.E., Noce C.M., Romano A.W., Machado N. 1994. Evolução sedimentar do Supergrupo Minas: 500 Ma de registro geológico no Quadrilátero Ferrífero, Minas Gerais, Brasil. Geonomos, 2:1-11.

Rodrigues L.C., Chemale F.Jr., Jost H. 1993. O posicionamento estratigráfico dos quartzitos da Serra do Caraça. Anais do VII Simp. Geol. de Minas Gerais, Bol. da Soc. Bras. Geol., Núcleo Minas Gerais, 12:34-38.

Rollinson H.R. 1993. Using geochimical data: Evaluation, Presentation, Interpretation. Ist ed. New York, Longman Scientific \& Technical, 352p.

Taylor S.R \& McLennan S.M. 1985. The continental crust: its composition and evolution. Blackwell Sci. Publ., 312p.

Teixeira W., Sabate P., Barbosa J., Noce C.M., Carneiro M.A. 2000. Archean and Paleoproterozoic Tectonic Evolution of the São Francisco Craton, Brazil. In: U.G Cordani, E.J. Milani, A. Thomaz Filho \& D.A. Campos (eds.), Tectonic Evolution of South America, $31^{\text {st }}$ IGC, Rio de Janeiro, $\mathrm{p}$. 101-137.

Walker R.G. 1978. Deep-water sandstone facies and ancient submarine fans: models for exploration for stratigraphic traps. Bull. Am. Assoc. Petrol. Geol., 62:932-966.

Walker R.G. 1984. Turbidites and associated coarse clastic deposits. In: R.G. Walker (ed.) Fácies Models, $2^{\text {nd }}$ ed., Geoscien. Can., Reprint. Ser., pp.171-188.

Walker R.G. 1992. Turbidites and submarine fans. In: R.G. Walker \& N.P. James (eds.), Fácies Models: Response to Sea-level Change. Geological Association of Canada, 409 p.

Manuscrito A-1200

Recebido em 10 de janeiro de 2001 Revisão dos autores em 01 de marco de 2002 Revisão accita em 05 de março de 2002 